\title{
Impact of the deep convection of isoprene and other reactive trace species on radicals and ozone in the upper troposphere
}

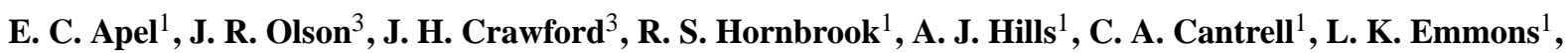 \\ D. J. Knapp ${ }^{1}$, S. Hall ${ }^{1}$, R. L. Mauldin III ${ }^{1, *{ }^{* *}}$, A. J. Weinheimer ${ }^{1}$, A. Fried ${ }^{2,10}$, D. R. Blake ${ }^{4}$. J. D. Crounse ${ }^{5}$, \\ J. M. St. Clair ${ }^{5}$, P. O. Wennberg ${ }^{5}$, G. S. Diskin ${ }^{3}$, H. E. Fuelberg ${ }^{6}$, A. Wisthaler ${ }^{7}$, T. Mikoviny ${ }^{7}$, W. Brune ${ }^{8}$, and \\ D. D. Riemer ${ }^{9}$ \\ ${ }^{1}$ Atmospheric Chemistry Division, National Center for Atmospheric Research, Boulder, Colorado, USA \\ ${ }^{2}$ Earth Observing Laboratory, National Center for Atmospheric Research, Boulder, Colorado, USA \\ ${ }^{3}$ NASA Langley Research Center, Hampton, Virginia, USA \\ ${ }^{4}$ School of Physical Sciences, University of California, Irvine, California, USA \\ ${ }^{5}$ California Institute of Technology, Pasadena, California, USA \\ ${ }^{6}$ Department of Meteorology, Florida State University, Tallahassee, Florida, USA \\ ${ }^{7}$ Institut für Ionenphysik \& Angewandte Physik, University of Innsbruck, Innsbruck, Austria \\ ${ }^{8}$ Pennsylvania State University, State College, PA, USA \\ ${ }^{9}$ Rosenstiel School of Marine and Atmospheric Science, University of Miami, Miami, Florida, USA \\ ${ }^{10}$ Institute for Arctic and Alpine Research, University of Colorado, Boulder, CO, USA \\ * now at: Department of Physics, 00014 University of Helsinki, Finland \\ ** now at: Department of Atmospheric and Oceanic Sciences, University of Colorado, Boulder, Colorado, USA
}

Correspondence to: E. C. Apel (apel@ucar.edu)

Received: 23 August 2011 - Published in Atmos. Chem. Phys. Discuss.: 5 October 2011

Revised: 10 January 2012 - Accepted: 12 January 2012 - Published: 27 January 2012

\begin{abstract}
Observations of a comprehensive suite of inorganic and organic trace gases, including non-methane hydrocarbons (NMHCs), halogenated organics and oxygenated volatile organic compounds (OVOCs), obtained from the NASA DC-8 over Canada during the ARCTAS aircraft campaign in July 2008 illustrate that convection is important for redistributing both long- and short-lived species throughout the troposphere. Convective outflow events were identified by the elevated mixing ratios of organic species in the upper troposphere relative to background conditions. Several dramatic events were observed in which isoprene and its oxidation products were detected at hundreds of pptv at altitudes higher than $8 \mathrm{~km}$. Two events are studied in detail using detailed experimental data and the NASA Langley Research Center (LaRC) box model. One event had no lightning $\mathrm{NO}_{\mathrm{x}}\left(\mathrm{NO}+\mathrm{NO}_{2}\right)$ associated with it and the other had substantial lightning $\mathrm{NO}_{\mathrm{x}}\left(\mathrm{LNO}_{\mathrm{x}}>1 \mathrm{ppbv}\right)$. When convective storms transport isoprene from the boundary layer to the upper troposphere and no $\mathrm{LNO}_{\mathrm{x}}$ is present, $\mathrm{OH}$ is reduced due to scavenging by isoprene, which serves to slow
\end{abstract}

the chemistry, resulting in longer lifetimes for species that react with $\mathrm{OH}$. Ozone and $\mathrm{PAN}$ production is minimal in this case. In the case where isoprene is convected and $\mathrm{LNO}_{\mathrm{x}}$ is present, there is a large effect on the expected ensuing chemistry: isoprene exerts a dominant impact on $\mathrm{HO}_{\mathrm{x}}$ and nitrogen-containing species; the relative contribution from other species to $\mathrm{HO}_{\mathrm{x}}$, such as peroxides, is insignificant. The isoprene reacts quickly, resulting in primary and secondary products, including formaldehyde and methyl glyoxal. The model predicts enhanced production of alkyl nitrates (ANs) and peroxyacyl nitrate compounds (PANs). PANs persist because of the cold temperatures of the upper troposphere resulting in a large change in the $\mathrm{NO}_{\mathrm{x}}$ mixing ratios which, in turn, has a large impact on the $\mathrm{HO}_{\mathrm{x}}$ chemistry. Ozone production is substantial during the first few hours following the convection to the UT, resulting in a net gain of approximately 10 ppbv compared to the modeled scenario in which $\mathrm{LNO}_{\mathrm{x}}$ is present but no isoprene is present aloft. 


\section{Introduction}

The upper troposphere (UT) is distinguished from the lower troposphere (LT) by low water vapor mixing ratios (10$300 \mathrm{ppmv})$ and cold temperatures $(210-235 \mathrm{~K})$. As a result, the primary source of $\mathrm{HO}_{\mathrm{x}}$ radicals from $\mathrm{O}\left({ }^{1} \mathrm{D}\right)+\mathrm{H}_{2} \mathrm{O}$ is one to two orders of magnitude smaller than at low altitudes. This characteristic allows for increasing competition of other $\mathrm{HO}_{\mathrm{x}}$ sources with altitude as the atmosphere gets drier (Wennberg et al., 1998; Jaegle et al., 2001). Peroxides have been identified as important $\mathrm{HO}_{\mathrm{x}}$ sources (e.g. Cohan et al., 1999). Studies over the past $15 \mathrm{yr}$ have shown oxygenated volatile organic compounds (OVOCs) to be ubiquitous in the atmosphere, reaching significant mixing ratios throughout the troposphere, even in remote regions (Singh et al., 1995). These species typically include acetone, methanol, and aldehydes, which can be transported from the LT to the UT or may be formed within the UT. When present in significant amounts, these species can have an important role in governing the production and destruction of ozone, a radiatively important gas (Wennberg et al., 1998; Shindell et al., 2008) and may be sources or sinks of $\mathrm{OH}$ and $\mathrm{HO}_{2}$. Although there is discussion in the community about the reliability of background tropospheric measurements of some of the short-lived species such as acetaldehyde (Millet et al., 2010), there is no controversy about the presence of methanol and acetone, relatively long-lived species, in the UT; a number of studies have observed these species, especially acetone, with different techniques and reasonable agreement (Wohlfrom et al., 1999; Karl et al., 2007).

The influence of convective transport on $\mathrm{HO}_{\mathrm{x}}$ precursors was first hypothesized by Chatfield and Crutzen (1984). Other experimental and theoretical studies have explored the influence of deep convection on the chemical composition of the UT (Pickering et al., 1992; Ridley et al., 1994; Jaegle et al., 1997; Prather and Jacob, 1997; Cohan et al., 1999; Barth et al., 2007; Huntrieser et al., 2011). The PRESTORM campaign in 1985 provided some of the first observations that clearly showed convective redistribution of ozone $\left(\mathrm{O}_{3}\right)$, nitric oxide (NO), carbon monoxide (CO), and to a lesser extent, non-methane hydrocarbons (NMHCs) in a mid-latitude storm (Dickerson et al., 1987). Subsequent modeling and analysis (Pickering et al., 1990) found that convective redistribution could dramatically increase ozone production in the UT by as much as a factor of four with peak net ozone production rates of $15 \mathrm{ppbv}$ per day. This increase was shown to rely on the transport of both NO and NMHCs (assumed) from the boundary layer as well as production of NO from lightning. Thus, transport, production of NO from lightning, and scavenging of soluble species were found to be important processes occurring in thunderstorms that affect the chemical composition of the troposphere. Enhancement at higher altitudes, notably of species with relatively short chemical lifetimes have been observed as well (Colomb et al., 2006) indicating that deep convection may redistribute boundary layer air into the mid- and upper-troposphere over short timescales during summertime in the mid-latitudes or throughout the year in the tropics (Marecal et al., 2006; Aschmann et al., 2009; Wang and Prinn, 2000).

The vertical tropospheric odd hydrogen budget received renewed attention with the advent of instruments capable of directly measuring $\mathrm{OH}$ and $\mathrm{HO}_{2}$ (Wennberg et al., 1995; Brune et al., 1998) and has been the subject of study for a number of years (Crawford et al., 1999; Olson et al., 2004). Although studies have illuminated some of the characteristics of the UT, there is still an incomplete understanding of its composition and chemistry as evidenced by comparisons of measurements with theory which have yielded inconsistencies from campaign to campaign (Jaegle et al., 1997, 1998; Brune et al., 1998, 1999; Crawford et al., 1999; Jaegle et al., 2001; Olson et al., 2004; Ren et al., 2008).

The impact of vertical transport on the photochemistry of the UT is intimately tied to the emissions of volatile organic compounds (VOCs) and $\mathrm{NO}_{\mathrm{x}}$. Thirteen hundred teragrams of reduced carbon compounds are released into the atmosphere each year from various biogenic and anthropogenic sources (Goldstein and Galbally, 2007). Likewise, $40 \mathrm{Tg}$ of $\mathrm{NO}_{\mathrm{x}}$ are released globally each year (Martin et al., 2003). The fraction of this $\mathrm{NO}_{\mathrm{x}}$ due to lightning remains uncertain at $\approx 2-20 \mathrm{Tg} \mathrm{N} \mathrm{yr}^{-1}$ (DeCaria et al., 2005; Schumann and Huntrieser, 2007), but it is known that large production occurs on local scales and from individual storms (Ridley et al., 2004). VOC and $\mathrm{NO}_{\mathrm{x}}$ species are distributed and mixed globally according to emission sources, species lifetimes and transport pathways. The distribution is highly variable and spatially dependent on emission source location and lifetimes for removal from the atmosphere of the emitted species. This transport occurs through simple advection and convection via turbulent mixing at scales that vary from the largest synoptic systems to microscopic mixing within an individual convective event. Complete vertical mixing in the troposphere is achieved in about one month. In the absence of rapid convection, longer-lived OVOCs, such as methanol and acetone, have a dominant influence on the chemistry of the UT. However, rapid convection by thunderstorms and pyroconvective storms (Fromm et al., 2000; Jost et al., 2004; Martin et al., 2010) can and does occur. This can inject shorter-lived $\mathrm{HO}_{\mathrm{x}}$ precursors such as hydrogen peroxide $\left(\mathrm{H}_{2} \mathrm{O}_{2}\right)$, if it is not scrubbed in the convective process, methyl hydroperoxide $\left(\mathrm{CH}_{3} \mathrm{OOH}\right)$ (Snow et al., 2007) and formaldehyde $\left(\mathrm{CH}_{2} \mathrm{O}\right)$ (Colomb et al., 2006; Stickler et al., 2006; Fried et al., 2008) to the UT. The July and August 2004 NASA INTEX-A project results showed that much of the UT region over the US is influenced by convection (Kiley and Fuelberg, 2006; Cooper et al., 2007; Singh et al., 2007; Hudman et al., 2007; Snow et al., 2007; Bertram et al., 2007; Fried et al., 2008) during the summer.

A recent modeling study that included a sophisticated deep convection parameterization into an isentropic Chemical Transport Model (CTM) showed that very short-lived 
species can reach and influence the tropical UT/LS (lower stratosphere) (Aschmann et al., 2009). Isoprene, a very shortlived species, has a large terrestrial source to the atmosphere $\left(\approx 500 \mathrm{Tg} \mathrm{yr}^{-1}\right.$, Guenther et al., 2006). When present at the surface during a convective event, it and/or its oxidation products have the potential to be transported to the UT. Another study, using a global three dimensional Lagrangian chemistry transport model (Collins et al., 1999), predicted a large influence from isoprene and its reaction products on the UT odd hydrogen budget over the tropical continents, where convection and VOC emissions from vegetation are collocated. Few experiments have provided an opportunity to test this model result with direct measurement of these species in the UT. In this paper, we present data showing the presence of isoprene and its oxidation products in the UT following convection. We use a Lagrangian implementation of the Langley box model (Crawford et al., 1999) to evaluate the chemical impact of this transport on UT composition.

The 2008 NASA Arctic Research of the Composition of the Troposphere from Aircraft and Satellite (ARCTAS) mission was part of the broader International Polar Year (IPY) collaborative effort POLARCAT (Polar Study using Aircraft, Remote Sensing, Surface Measurements and Models, of Climate, Chemistry, Aerosols, and Transport). ARCTAS was a multi-platform field campaign involving airborne measurements from three NASA aircraft (DC-8, P-3B and B-200), a number of ground-based measurement sites and satellite observations. Coordination with other POLARCAT activities included the NOAA-led Aerosol, Radiation and Cloud Processes affecting Arctic Climate (ARCPAC) and the Greenland Aerosol and Chemistry Experiment (DLR-GRACE). An overview of the ARCTAS campaign has been published and gives a detailed description of all the measurement platforms and supporting investigations used during the campaign (Jacob et al., 2010).

The NASA DC-8 was involved in the three major components of the ARCTAS campaign: (a) ARCTAS-A, based in Fairbanks, Alaska with research flights in the Arctic regions of Canada, Alaska and Greenland between 1-19 April 2008, (b) ARCTAS-CARB, based in Palmdale, California, in cooperation with the Californian Air Resources Board (CARB) with flights over California between 18-26 June 2008, and (c) ARCTAS-B (26 June-14 July 2008), based in Alberta, Canada. The data presented in this paper were obtained during the ARCTAS-B experiment and particular emphasis is placed on the July 04 flight during which significant convection was observed on several occasions.

\section{Description of measurements and model}

\subsection{Measurements}

During the ARCTAS campaign the NASA DC-8 aircraft was equipped to measure an extensive suite of gas-phase and aerosol species. The full payload is documented by Jacob et al. (2010). In this analysis we used the measurements listed in Table 1. A number of species were measured by more than one technique. In each such case, we used our discretion based on supporting data in selecting the most appropriate technique to be used in the analysis, as discussed below. $\mathrm{OH}$ and $\mathrm{HO}_{2}$ were measured both by the NCAR chemical ionization mass spectrometers (Mauldin et al., 1999; Cantrell et al., 2003; Hornbrook et al., 2011a) and the Pennsylvania State laser induced fluorescence (LIF) technique (Faloona et al., 2004), but we most often use the LIF OH and $\mathrm{HO}_{2}$ measurements because during convection events observed at high altitudes, the data coverage from the LIF instrument was more complete.

NCAR deployed the Trace Organic Gas Analyzer (TOGA) which uses fast online gas chromatography coupled with mass spectrometry (GC-MS) to analyze a 40$\mathrm{s}$ integrated sample once every two minutes. This system is described by Apel et al. (2010) and, specifically, for the ARCTAS campaign by Hornbrook et al. (2011b). Thirty VOCs were continuously measured with this technique including $\mathrm{NMHC}\left(\mathrm{C}_{4}\right.$ and $\mathrm{C}_{5}$ alkanes, isoprene, benzene, toluene and the $\mathrm{C}_{8}$-aromatic and $\mathrm{C}_{9}$-aromatic VOCs), oxygenated VOCs (OVOCs; acetaldehyde $\left(\mathrm{CH}_{3} \mathrm{CHO}\right)$, methanol $\left(\mathrm{CH}_{3} \mathrm{OH}\right)$, ethanol $\left(\mathrm{C}_{2} \mathrm{H}_{5} \mathrm{OH}\right)$, acetone $\left(\mathrm{CH}_{3} \mathrm{COCH}_{3}\right)$, propanal $\left(\mathrm{C}_{2} \mathrm{H}_{5} \mathrm{CHO}\right)$, methacrolein (MACR; $\mathrm{CH}_{2} \mathrm{C}\left(\mathrm{CH}_{3}\right) \mathrm{CHO}$ ), methyl vinyl ketone (MVK; $\left.\mathrm{CH}_{2} \mathrm{CHCOCH}_{3}\right)$, butanal $\left(\mathrm{C}_{3} \mathrm{H}_{7} \mathrm{CHO}\right)$, methyl ethyl ketone $\left(\mathrm{MEK} ; \mathrm{C}_{2} \mathrm{H}_{5} \mathrm{COCH}_{3}\right)$ methyl tertbutyl ether (MTBE; $\left.\mathrm{C}\left(\mathrm{CH}_{3}\right)_{3} \mathrm{OCH}_{3}\right)$ ), halogenated VOCs including chloromethane $\left(\mathrm{CH}_{3} \mathrm{Cl}\right)$, bromomethane $\left(\mathrm{CH}_{3} \mathrm{Br}\right)$, dichloromethane $\left(\mathrm{CH}_{2} \mathrm{Cl}_{2}\right)$, chloroform $\left(\mathrm{CHCl}_{3}\right)$, tetrachloromethane $\left(\mathrm{CCl}_{4}\right)$, and acetonitrile $\left(\mathrm{CH}_{3} \mathrm{CN}\right)$ and dimethylsulfide (DMS; $\mathrm{CH}_{3} \mathrm{SCH}_{3}$ ).

In addition to TOGA, two other instruments, a protontransfer-reaction mass spectrometer (PTR-MS) and a whole air sampler (WAS), measured some of the above VOCs as well as additional species. In the PTR-MS deployed here, VOCs are ionized in proton transfer reactions with $\mathrm{H}_{3} \mathrm{O}^{+}$ ions and the product ions are measured with a quadrupole mass spectrometer (Lindinger et al., 1998; de Gouw and Warneke, 2007). The product ion mass-to-charge $(\mathrm{m} / \mathrm{z}) \mathrm{ra}$ tio is not a unique indicator of the identity of a trace gas so different VOCs with the same $m / z$ cannot be separately measured (de Gouw et al., 2003). However, the measured $\mathrm{m} / \mathrm{z}$, may be predominantly from one molecule. During ARCTAS, this is believed to be the case for $m / z$ ratios that correspond with the detection of methanol $(\mathrm{m} / \mathrm{z}=33)$, acetonitrile $(\mathrm{m} / \mathrm{z}$ $=42)$, acetaldehyde $(\mathrm{m} / \mathrm{z}=45)$, acetone $(\mathrm{m} / \mathrm{z}=59)$, benzene $(\mathrm{m} / \mathrm{z}=79)$, and toluene $(\mathrm{m} / \mathrm{z}=93)$. In the absence of fires, $\mathrm{m} / z=69$ corresponds predominantly to isoprene. When fires are present, $\mathrm{m} / \mathrm{z}, 69$ also includes contributions from furan $\left(\mathrm{C}_{4} \mathrm{H}_{4} \mathrm{O}\right)$ and a number of alkenes. Similar arguments hold for $m / z=71$ which does not represent a unique species; the major contributors to this signal are believed to be MACR 
Table 1. Measurements used in this paper.

\begin{tabular}{lll}
\hline Species & Method & Reference \\
\hline $\mathrm{NO}, \mathrm{NO}_{2}, \mathrm{O}_{3}$ & Chemiluminescence $^{\mathrm{a}}$ & Carroll et al. (1992) \\
$\mathrm{NMHCs}, \mathrm{OVOCs}, \mathrm{CH}_{3} \mathrm{CN}$ & GC-MS $^{\mathrm{a}}$ & Apel et al. (2010) \\
$\mathrm{CO}, \mathrm{H}_{2} \mathrm{O}$ & TDLAS $^{\mathrm{b}}$ & Sachse et al. (1991); Diskin et al. (2002) \\
$\mathrm{OH}, \mathrm{HO}_{2} \mathrm{OH}, \mathrm{HO}_{2}$ & LIF $^{\mathrm{c}} \mathrm{CIMS}^{\mathrm{d}}$ & Faloona et al. (2004); Cantrell et al. (2003) \\
$\mathrm{UV}$ photolytic frequencies & Spectral radiometry $^{\text {S }}$ & Shetter and Muller (1999) \\
$\mathrm{NMHCs}^{\mathrm{H}}$ & GC-FID $^{\mathrm{e}}$, GC-MS & Simpson et al. (2010) \\
$\mathrm{H}_{2} \mathrm{O}_{2}, \mathrm{CH}_{3} \mathrm{OOH}$ & CIMS $^{\mathrm{O}}$ & Crounse et al. (2006); St. Clair et al. (2010) \\
$\mathrm{H}_{2} \mathrm{CO}$ & DFGAS $^{\mathrm{f}}$ & Weibring et al. (2010) \\
$m / z=69^{*}, m / z=71^{*}$ & PTR-MS $^{\mathrm{g}}$ & Lindinger et al. (1998) \\
\hline
\end{tabular}

${ }^{a}$ Gas Chromatography - Mass Spectrometry; ${ }^{\mathrm{b}}$ Tunable Diode Laser Absorption Spectroscopy; ${ }^{\mathrm{c}}$ Laser Induced Fluorescence; ${ }^{\mathrm{d}}$ Chemical Ionization Mass Spectrometry; ${ }^{\mathrm{e}}$ Gas Chromatography - Flame Ionization Detection; ${ }^{\mathrm{f}}$ Difference Frequency Generation Absorption Spectrometry; ${ }^{\mathrm{g}}$ Proton Transfer Reaction Mass Spectrometry;

* In the absence of ?res, the primary contributor to the $m / z=69$ ion is isoprene. $m / z=71$ principally represents the sum of methacrolein and methyl vinyl ketone. See text for further. discussion.

and MVK. The reported PTR-MS measurement frequency is approximately once each 5-10 s for most compounds.

Whole air samples (WAS) were collected during the flights through a forward facing non-heated stainless steel inlet $\left(1 / 4^{\prime \prime}\right)$ into electropolished stainless steel flasks and pressurized to 35 psig with a metal bellows pump (Senior Flexonics, MB 602). The WAS were analyzed afterwards in the laboratory by gas chromatography (GC) on six separate columns using flame ionization detection (FID), MS, and electron capture detection (ECD). Reported OVOCs included methanol, ethanol, acetone, MEK and MVK. There were 168 canisters available for each flight. The canister sampling frequency varied depending on location and altitude, but averaged approximately one integrated sample every four minutes. The sample integration period was often tied to the TOGA integration time for maximum overlap but at higher altitudes the WAS integration time increased because concomitant lower pressures determined the flow rate into the canister collection system. See Colman et al. (2001) and Simpson et al. (2010) for more details on WAS. In addition to the TOGA measurements, a subset of the WAS and PTR-MS measurements was used as input to model simulations described below.

All ARCTAS data are available in a public archive (http: //www-air.larc.nasa.gov/cgi-bin/arcstat-c).

\subsection{Model}

Box model simulations were conducted using the NASA Langley time-dependent photochemical box model (Crawford et al., 1999; Olson et al., 2001, 2006). The standard implementation of the model is a diurnal steady state (DSS) mode, in which the model calculates for each set of measurements the associated self-consistent diurnal profile of radical and other computed species determined from the constraint of longer-lived precursors to measured concentrations (see discussion in Fried et al., 2008). Computed radical concen- trations at the same point in time as the measurement are then used as the instantaneous model results. The time base used for the DSS simulations during ARCTAS is the NASA 60s merge file (http://www-air.larc.nasa.gov/cgi-bin/arcstat-c). For this model implementation, the minimum set of input constraints includes observations of $\mathrm{O}_{3}, \mathrm{CO}, \mathrm{NO}_{2}$, $\mathrm{NMHCs}$, acetone, methanol, temperature, $\mathrm{H}_{2} \mathrm{O}$ pressure, photolysis frequencies; additional optional constraints that may be used if desired and when available include measurements of $\mathrm{H}_{2} \mathrm{O}_{2}, \mathrm{CH}_{3} \mathrm{OOH}, \mathrm{HNO}_{3}$, and PAN. For this study, the Langley box model was also run in a Lagrangian mode, whereby after model initialization, the constraints are relaxed and the model predicts the full chemical evolution of radicals and their radical precursors. After model initialization, an injection of selected species may be introduced, so as to follow the chemical evolution of a non-equilibrium injection, such as during a convective event.

\section{Results and discussion}

The data discussed below encompass all measurements taken on four ARCTAS-B research flights from 29 June through 5 July, the combined flight tracks of which are shown in Fig. 1 with individual flights colored uniquely. Figure 2 shows vertical profiles for several species observed during this time period. Formaldehyde was measured by the Difference Frequency Generation Absorption Spectrometer (DFGAS, Weibring et al., 2010), $\mathrm{NO}$ and $\mathrm{NO}_{2}$ were measured by the NCAR Chemiluminescence instrument (Carroll et al., 1992), and all other observations are from the TOGA measurements. These species span a broad reactivity/lifetime range from formaldehyde, a fast-reacting photochemically labile species $(\tau \approx$ hours), to methanol, a slow-reacting, long-lived species ( $\tau \approx$ one week). Despite differences in the photochemical behavior of these two species, the vertical 
a)

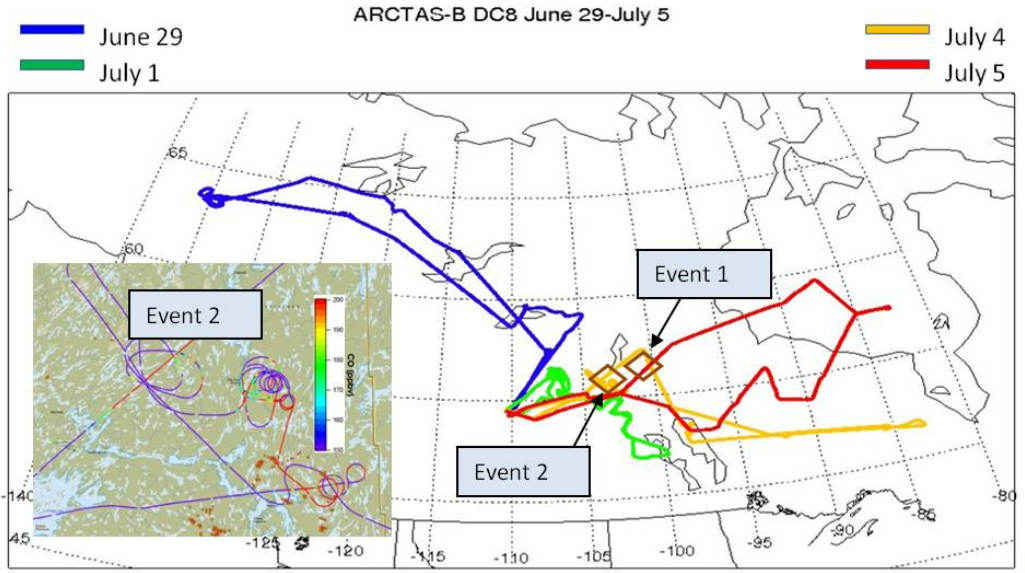

b)
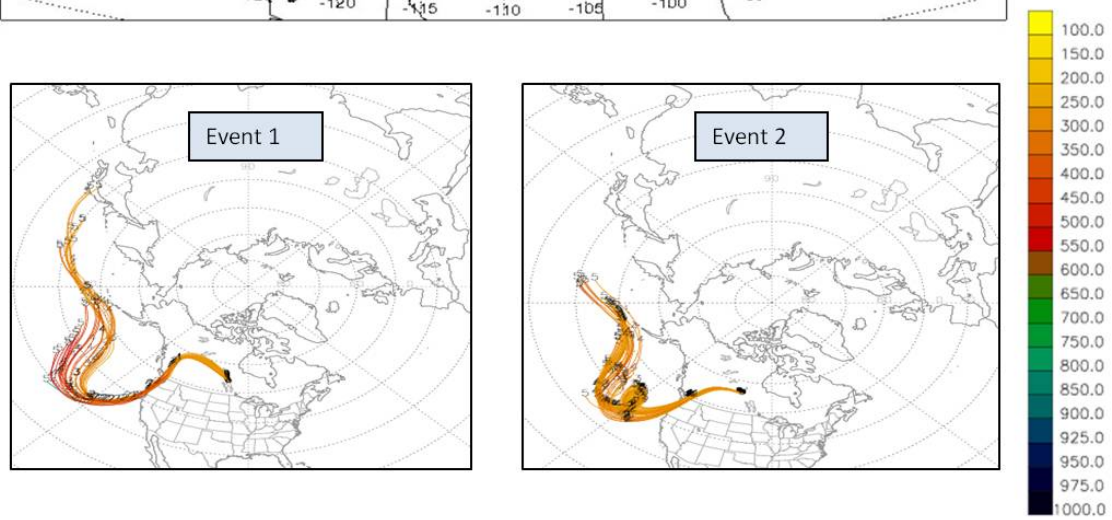

Fig. 1. ARCTAS B research flight paths taken by the NASA DC-8 between 29 June and 5 July (a) color-coded by flight date. Event 1 and 2 locations are shown by diamonds. Inset shows the flight track near event 2, color-coded by CO mixing ratios. (b) 5-day back trajectories for events 1 and 2, respectively.

profiles reveal high mixing ratios at both the surface and high altitude, indicating that convection has played an important role in the distribution of these species in the troposphere over Canada. In the figure, the data are separated into observations in biomass burning-influenced air masses, as determined by enhancements in $\mathrm{CH}_{3} \mathrm{CN}, \mathrm{HCN}$ and $\mathrm{CO}$, and observations in air masses not influenced by biomass burning. The criteria used for identifying biomass burning plumes are described by Hornbrook et al. (2011b). It is interesting to note the very high mixing ratios of trace gases observed at altitudes over $10 \mathrm{~km}$.

On 4 July 2008 (ARCTAS research flight 19) the DC-8 encountered several events for which there was strong chemical evidence that rapid convection had occurred. We will focus on two of those events and label them event 1 and event 2. Figure 3 shows the time series of isoprene and its oxidation products, MACR and MVK, observed during the entire flight. At times, in the mid- and upper-troposphere, these species are present in the 200-600 pptv range. For air encountered in the boundary layer, mixing ratios of these species are in the range of $400 \mathrm{pptv}$ to greater than $1 \mathrm{ppbv}$. The occurrence of events 1 and 2 is indicated by the gray regions.

\subsection{Estimation of transport lifetime using photochemical age}

Convective cells are capable of rapidly transferring boundary layer air up to high altitudes. The time scale for this process can vary significantly, depending on a number of physical parameters, but updraft velocities ranging from 1 to greater than $10 \mathrm{~m} \mathrm{~s}^{-1}$ are not uncommon, resulting in a timescale of hours to minutes for transferring boundary layer air to altitudes greater than $10 \mathrm{~km}$. This rapid convection allows for the possibility of even the shortest-lived trace species to reach the UT. Additionally, screening by large anvil clouds during active convection decreases the ultraviolet actinic light flux, which reduces the $\mathrm{OH}$ production and causes lower overall $\mathrm{OH}$ concentrations. Low $\mathrm{OH}$ concentrations and short residence times of reduced substances in boundary-layer air during convection combine to facilitate the transport of highly reactive gases to the UT. However, soluble or semi-soluble species are subject to washout during the convection process. In principle, the transport time can be estimated by calculating the photochemical age of the convected air mass.

A number of methods have been used to estimate the photochemical age of an air parcel. One method is to 

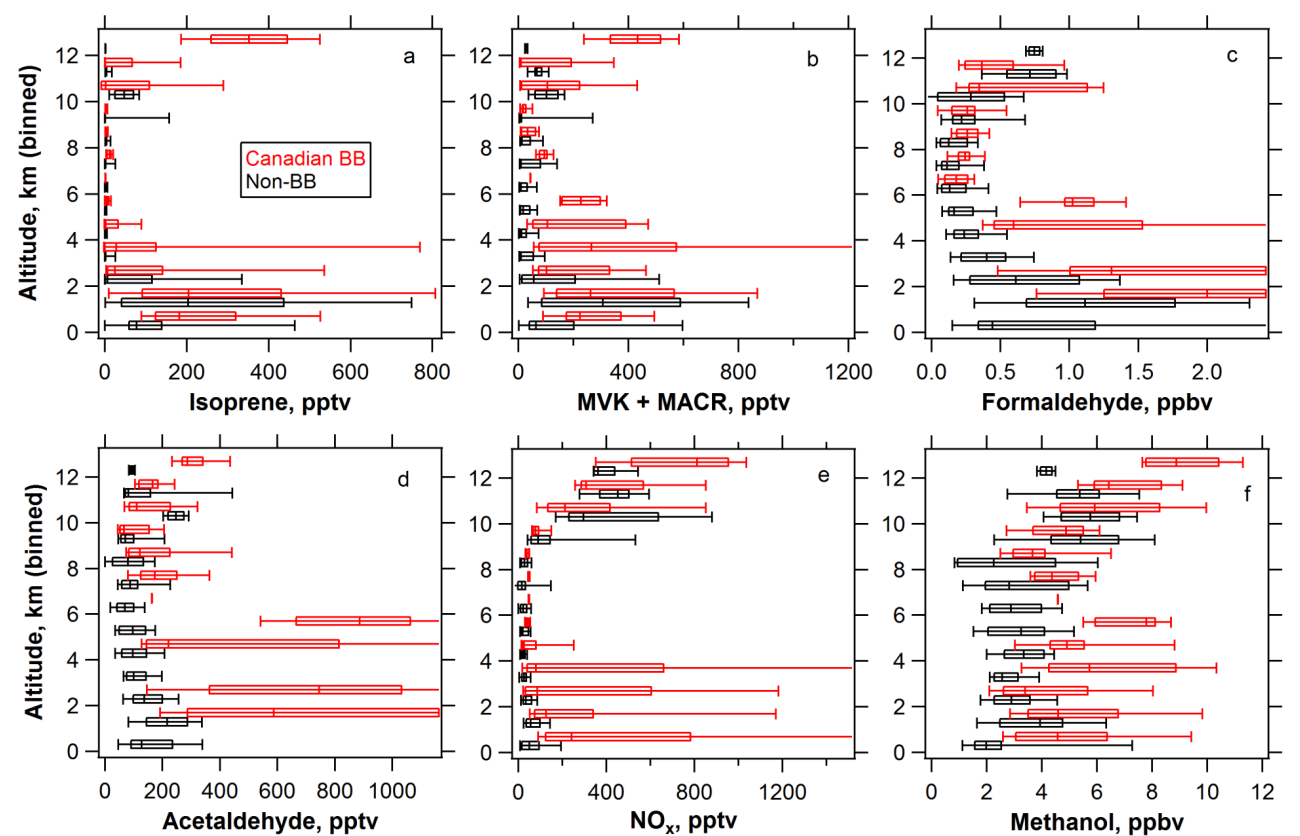

Fig. 2. Vertical profiles for select VOCs. Data are represented as box and whisker plots showing the median, lower quartile, upper quartile and the 10th and 90th percentiles of the recorded data. Data are binned in $1 \mathrm{~km}$ increments. Plots in black are not influenced by biomass burning whereas red plots, which are slightly offset from the black plots for clarity, represent data that have a Canadian biomass burning signature.

use parent-daughter (reaction product) kinetic relationships. Bertman et al. (1995) and Perring et al. (2010) used butane/butyl nitrate as the pair. For biogenically influenced airmasses, isoprene and either reaction product MVK or MACR can be used (e.g. Apel et al., 2002). In either case the system of kinetic equations can be solved for time:

$t=\ln \left(1-\frac{\frac{[B]}{[A]} \cdot\left(k_{2}-k_{1}\right)}{\alpha \cdot k_{1}}\right) /\left(\left(k_{1}-k_{2}\right) \cdot[\mathrm{OH}]\right)$

$[A]$ is the parent mixing ratio and $[B]$ is the daughter mixing ratio, $k_{1}$ and $k_{2}$ are the rate constants for the respective parent and daughter with $\mathrm{OH}$ and in the case of butyl nitrate it also includes the photolysis rate, $\alpha$ is the branching ratio and $[\mathrm{OH}]$ is the average mixing ratio of $\mathrm{OH}$ over the reaction time for the reaction time being calculated.

This equation holds when (1) no fresh emissions of $A$ are introduced during the trajectory for which the lifetime is calculated, (2) there are no direct emissions of the daughter reaction product, $B$, and (3) there are no losses via wet or dry deposition. Applying this methodology and using the butane and butyl nitrate as the parent/daughter we arrive at a photochemical age of $50 \mathrm{~h}$ for the air parcel sampled during convective event 1 and $82 \mathrm{~h}$ for the air parcel sampled during convective event 2. Similarly, using isoprene/MVK as the parent/daughter we derive respective photochemical ages of $10 \mathrm{~h}$ and $3.5 \mathrm{~h}$ for the air sampled in events 1 and 2 . Clearly there are some problems with applying this methodology in this particular case. Discussion of these problems

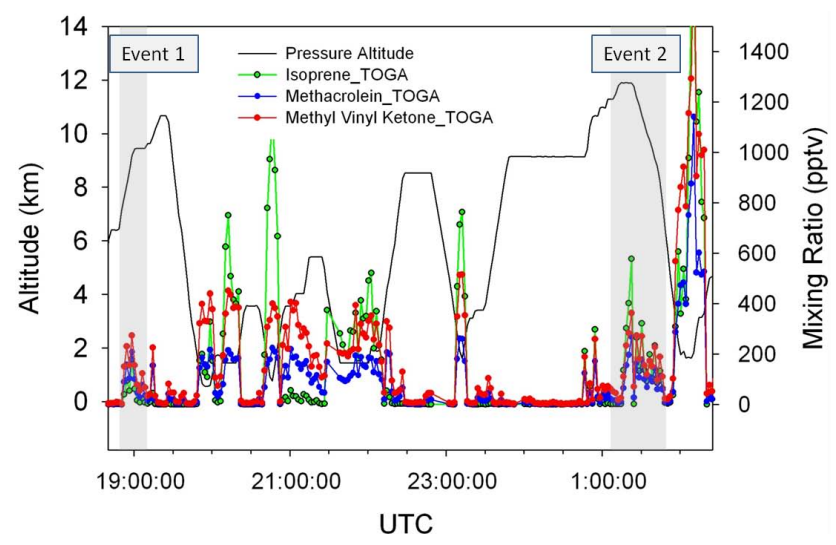

Fig. 3. Time series plot of altitude, isoprene, and first generation reaction products methacrolein and methyl vinyl ketone during the 4 July 2008 ARCTAS DC-8 flight. Events 1 and 2 are labeled.

helps illuminate some of the features of these two convective events. In this region of Canada, boundary layer air is usually removed in space and time from any nearby anthropogenic sources. This air, which typically may have an anthropogenic $\mathrm{OH}$ reactivity component of less than $1 \mathrm{~s}^{-1}$, is primarily and most recently influenced by the local boreal forest that is rich in biogenic emissions. Thus, the composition of the anthropogenic component of the boundary layer air prior to convection is aged and the biogenic component 


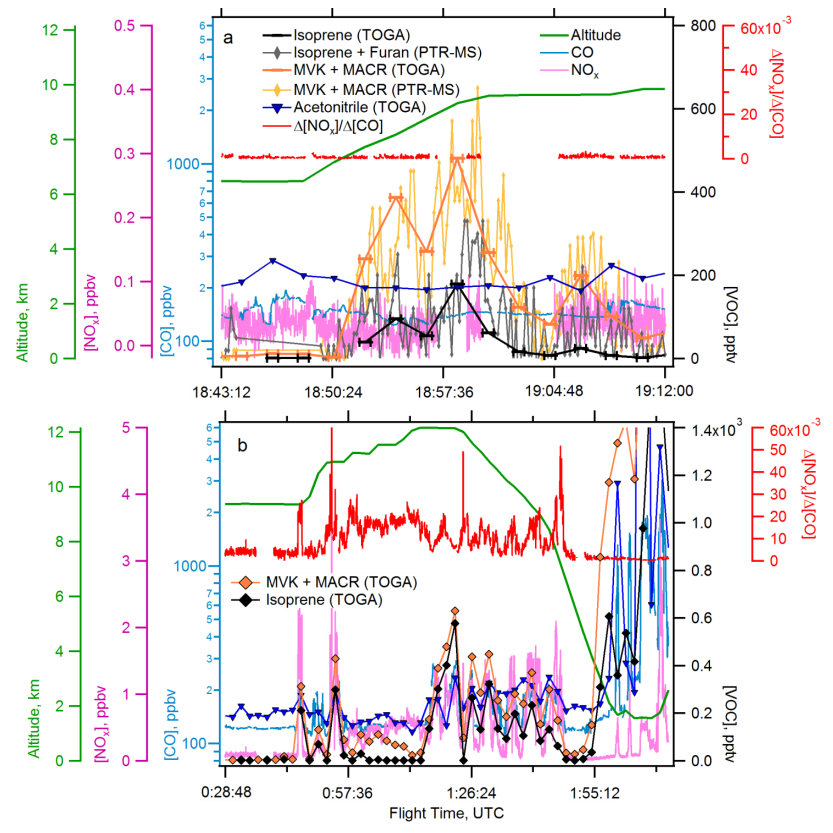

Fig. 4. Expanded view time series plot of a number of parameters for (a) event 1 and (b) event 2. See Table 1 for information on the techniques used to make these measurements. The bars representing the TOGA isoprene and MVK + MACR measurements indicate the integration time for sample collection (40 s). See text for a full description.

is much fresher. To first order, the biogenic parent/daughter relationship gives a better estimation of the "age" or transport lifetime of the convective events, albeit an upper limit since some degree of photochemical aging still may have occurred prior to the convective transport. Complicating matters, there is substantial biomass burning occurring in this region; biomass burning is known to result in the emissions of substantial amounts of VOCs, including direct emissions of butyl nitrate (Friedli et al., 2001) and isoprene and its oxidation products (Karl et al., 2007). In addition, $[\mathrm{OH}]$ is not known along the trajectory taken by the measured air parcel and in fact can vary substantially. We will examine this issue further in our discussion of event 2 below.

\subsection{Experimental observations of convective events 1 and 2}

Figure $4 \mathrm{a}$ shows an expanded time series plot of the convective event 1 shown in Fig. 3 and includes several key species along with the altitude profile. Both TOGA and PTR-MS measurements are shown here. Isoprene is present at 200-300 pptv at approximately $9 \mathrm{~km}$. Methyl vinyl ketone and methacrolein are, interestingly, both present at higher mixing ratios than isoprene $(\approx 500 \mathrm{pptv})$. This is usually not the case in studies reported in the literature (mostly ground-based measurements) since isoprene is the emitted species (in the absence of fire emissions) and MVK and
MACR are the reaction products with branching ratios of approximately 0.32 and 0.23 respectively (Atkinson, 1994). These branching ratios may actually be lower under these relatively low $\mathrm{NO}_{\mathrm{x}}$ conditions (e.g. Paulot et al., 2009). Also, MVK and MACR have significantly higher deposition velocities than isoprene (Karl et al., 2010). Mitigating these physical and chemical realities is the fact that isoprene has a significantly higher reaction rate with $\mathrm{OH} \quad\left(k_{\mathrm{OH}}=(1.02 \pm 0.09) \times 10^{-10} \mathrm{~cm}^{3}\right.$ molecule ${ }^{-1} \mathrm{~s}^{-1}$ at $295 \mathrm{~K}$, Poppe et al., 2007) than MVK $\left(k_{\mathrm{OH}}=(1.78 \pm 0.08) \times 10^{-11} \mathrm{~cm}^{3}\right.$ molecule ${ }^{-1} \mathrm{~s}^{-1}$ at $300 \mathrm{~K}$, Chuong and Stevens, 2004) or MACR $\left(k_{\mathrm{OH}}=(3.22 \pm\right.$ $0.10) \times 10^{-11} \mathrm{~cm}^{3}$ molecule ${ }^{-1} \mathrm{~s}^{-1}$ at $300 \mathrm{~K}$, Chuong and Stevens, 2004). Thus, in more aged air, removed from sources and deposition media, the ratio is expected to skew in favor of the oxidation products over isoprene. High $\mathrm{OH}$ levels can accelerate the redistribution from isoprene to reaction products. This pattern of enhanced oxidation products relative to isoprene in convective events was predicted by Collins et al. (1999) based on the fact that the oxidation products have longer lifetimes. Other features to note in the figure are the low $\mathrm{NO}_{\mathrm{x}}$ values $(10-100 \mathrm{pptv})$ and pedestrian $\mathrm{CO}$ values $(<200 \mathrm{ppbv})$. Below, this will be contrasted to convective event 2 . The acetonitrile mixing ratios indicate little or no fire influence. Figure $1 \mathrm{~b}$ shows the five-day back trajectory for this measurement time period showing exposure to the relatively unpopulated western Canada. Radar images (not shown) do not indicate the presence of a storm nearby so the elevated mixing ratios observed here result from convection that took place sometime prior to being intercepted by the DC- 8 .

Figure $4 \mathrm{~b}$ is similar to Fig. $4 \mathrm{a}$, but for convective event 2. Event 2 was a well-structured cumulonimbus $(\mathrm{Cb})$. During this event, isoprene mixing ratios are as high as $600 \mathrm{pptv}$ and the sum of MVK and MACR also reach mixing ratios of $600 \mathrm{pptv}$ at $12 \mathrm{~km}$. (Only the TOGA measurements are shown here since this air-mass has been influenced by fire which complicates the interpretation of the PTR-MS data). This is indicative of a younger air mass, relative to event 1 , or one which has aged with a lower average $[\mathrm{OH}]$. Other features to note are the high $\mathrm{NO}_{\mathrm{x}}$ values and the elevated $\mathrm{CO}$. The apparent structure seen in the $\mathrm{CO}, \mathrm{NO}_{\mathrm{x}}$ and $\Delta \mathrm{NO}_{\mathrm{x}} / \Delta \mathrm{CO}$ ratios is due to the pattern flown by the aircraft during this event. The plane flew a downward spiral pattern through the outflow of the convective event and the structure is the result of being in the outflow region, then exiting the outflow and measuring background or near-background air, and then reentering the outflow. This flight pattern can be seen in the inset in Fig. 1a.

A closer look at the $\mathrm{NO}_{\mathrm{x}}$ trace (Fig. $4 \mathrm{~b}$ ) reveals that prior to encountering the convected air, the observed mixing ratios of $\mathrm{NO}_{\mathrm{x}}$ were quite low (less than $100 \mathrm{pptv}$ ). Similarly, $\mathrm{NO}_{\mathrm{x}}$ mixing ratios continue to fall below $100 \mathrm{pptv}$ upon exiting the updraft on the downward spiral. Within the outflow, however, the $\mathrm{NO}_{\mathrm{x}}$ is as high as 2 ppbv. The observed 
CO mixing ratios are also elevated by approximately 60 $70 \mathrm{ppbv}$ in the convected air compared to the approximate 120-ppbv background air. Observation of the $\Delta \mathrm{NO}_{\mathrm{x}} / \Delta \mathrm{CO}$ ratio (red trace) during the event $\left(\approx 10-50 \times 10^{-3}\right)$ and then during the boundary level run $(<2)$ immediately following descent, where the inflow (or something approximating the inflow) to the convective event was sampled, reveals that the large majority of the $\mathrm{NO}_{\mathrm{x}}(>80 \%)$ was from lightning, principally in the form of NO. The remainder is the result of convected boundary layer air that is enhanced in $\mathrm{NO}_{\mathrm{x}}$ due to fire activity. Hornbrook et al. (2011b) show that the boreal fires of Canada generally produce relatively little $\mathrm{NO}_{\mathrm{x}}$, likely because these fires tend to be in wetlands with a high water content in the burning vegetation and are therefore often in the low temperature smoldering stage. In any case the $\Delta \mathrm{NO}_{\mathrm{x}} / \Delta \mathrm{CO}$ ratio is quite constant during this period when lightning is not present.

The $[\mathrm{CO}]$ in and out of the event can yield information on the amount of boundary layer air entrainment if the inflow is well characterized. As mentioned above, it is likely that some reasonable fraction of the inflow to the convective storm was sampled. The acetonitrile trace clearly shows that the air encountered in the inflow was influenced by burning, similar to sampled outflow. However, it has not been possible to definitively ascertain the correspondence of the inflow to the outflow through tracer analysis comparisons. Thus, since we do not know precisely the inflow conditions we cannot provide an accurate estimate of the amount of entrainment.

Observed peroxides can help identify if an air mass has been transported via a convective event because $\mathrm{H}_{2} \mathrm{O}_{2}$ is highly water soluble whereas $\mathrm{CH}_{3} \mathrm{OOH}$ is not very soluble (Snow et al., 2007). Figure 5 shows a plot of $\mathrm{H}_{2} \mathrm{O}_{2}$, $\mathrm{CH}_{3} \mathrm{OOH}$, the ratio of these species, and $\mathrm{NO}_{\mathrm{x}}$ observed during event 2. Elevated $\mathrm{NO}_{\mathrm{x}}$ is primarily $\mathrm{LNO}_{\mathrm{x}}$ and indicates when the plane is sampling convected species. The $\mathrm{H}_{2} \mathrm{O}_{2} / \mathrm{CH}_{3} \mathrm{OOH}$ ratio is lower in the vicinity of the convective system (cloud) compared to being outside of the system and $\mathrm{H}_{2} \mathrm{O}_{2}$ is suppressed relative to $\mathrm{CH}_{3} \mathrm{OOH}$ when passing in and out of the cloud as evidenced by the anti-correlation between the $\mathrm{H}_{2} \mathrm{O}_{2} / \mathrm{CH}_{3} \mathrm{OOH}$ ratio and $\mathrm{NO}_{\mathrm{x}}$. This clearly shows that wet deposition of $\mathrm{H}_{2} \mathrm{O}_{2}$ has taken place. It is also interesting to note that $\mathrm{CH}_{3} \mathrm{OOH}$ shows very little enhancement in the outflow. This point will be discussed further below.

\subsection{Modeling of event 2 to put bounds on convective transport time}

The focus of this paper is not on gaining an understanding of the physical processes involved in the convection of the boundary layer air to high altitudes, but it is of interest to use modeling results to explore scenarios that help put bounds on estimates for the time between "injection" of boundary layer species and detection aloft in the outflow. Recall that the upper limit derived for the transport time using photochemical age considerations from equation (1) (using the biogenic pair

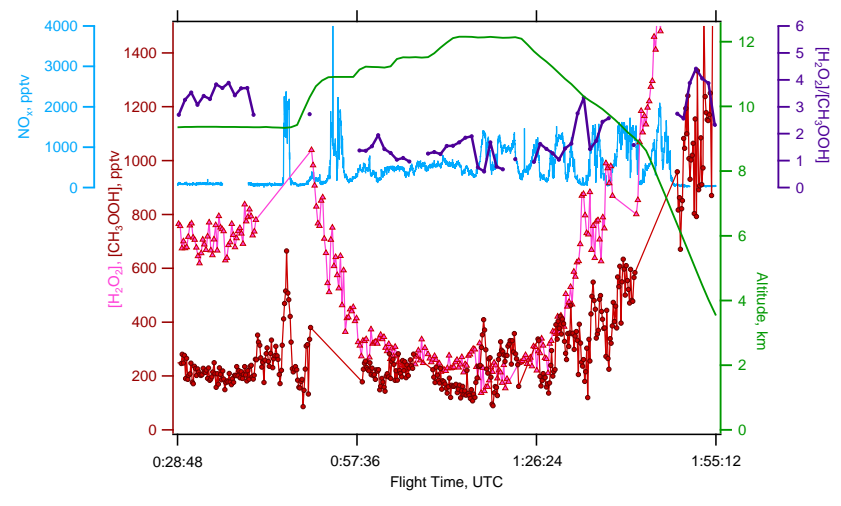

Fig. 5. Expanded view time series plot for peroxides, $\mathrm{NO}_{\mathrm{x}}$ and altitude for event 2 .

of isoprene and MVK) indicated that the air we encountered in event 2 was $3.5 \mathrm{~h}$ old (with many caveats) whereas convection dynamics suggest that strong updrafts could result in significantly shorter convection times. The NASA LaRC box model was employed in its Langrangian formulation to help put constraints on this time. The convection event uplifts boundary layer air containing species of interest such as $\mathrm{NO}_{\mathrm{x}}$ and isoprene into the UT. The approach taken here is to mimic, in a simplified way, this convection event by "injecting" a reasonable estimate of $\mathrm{NO}_{\mathrm{x}}(1500 \mathrm{pptv})$ and boundary layer isoprene (1 ppbv) values into the model and let the species evolve as a function of time after injection. By superimposing the aircraft data that were obtained at the time that the convected species were intercepted, which was approximately 18:30 local sun time on 4 July, we can compare the predicted concentration of the species with observations to better estimate the time from injection. Figure $6 \mathrm{a}$ and $\mathrm{b}$ show the results of this exercise. Figure $6 \mathrm{a}$ assumes the $3.5 \mathrm{~h}$ upper limit for the transport time and shows the predicted (model) and measurement (red points) results for a number of species if the "injection" took place at 15:00 local sun time. Figure $6 \mathrm{~b}$ shows results for "injection" of the boundary layer values at $17: 00 \mathrm{~h}$ local sun time, i.e. $1.5 \mathrm{~h}$ before the event was observed. Results in black are for clear sky J-values and results in blue are for $0.5 \times$ the clear sky J-values. The latter values are similar in magnitude to the $\mathrm{J}$-values observed near the top of the updraft. Figure 6a shows that even under the reduced J-value scenario (blue trace), which is unlikely for the span of $3.5 \mathrm{~h}$, isoprene would have decayed to lower levels than the spread of the observations (150-600 pptv) indicate (red points show the range of isoprene and other measured parameters when the plume was intercepted). The modeled results depicted in Fig. $6 \mathrm{~b}$ are more representative of the observed data. The observed isoprene values are in the range predicted by the model when using clear sky and $0.5 \times$ clear sky J-values. The other observed parameters show consistency with this one-hour scenario suggesting that the lifting of boundary layer air to the UT via convection (event 2) is 
a) 3.5 hours
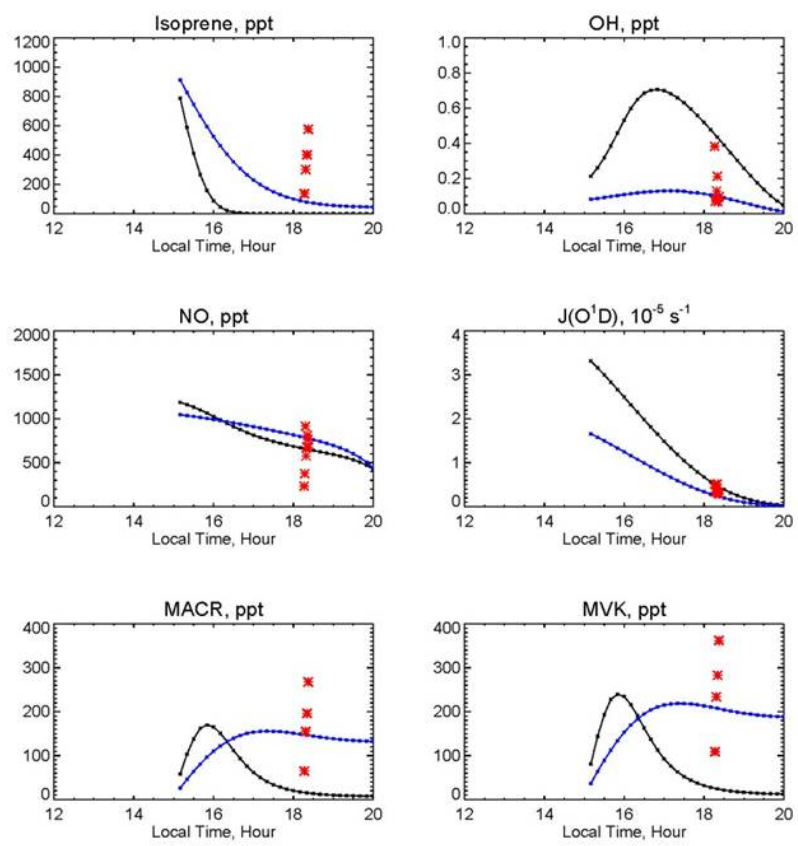

b) 1.0 hours
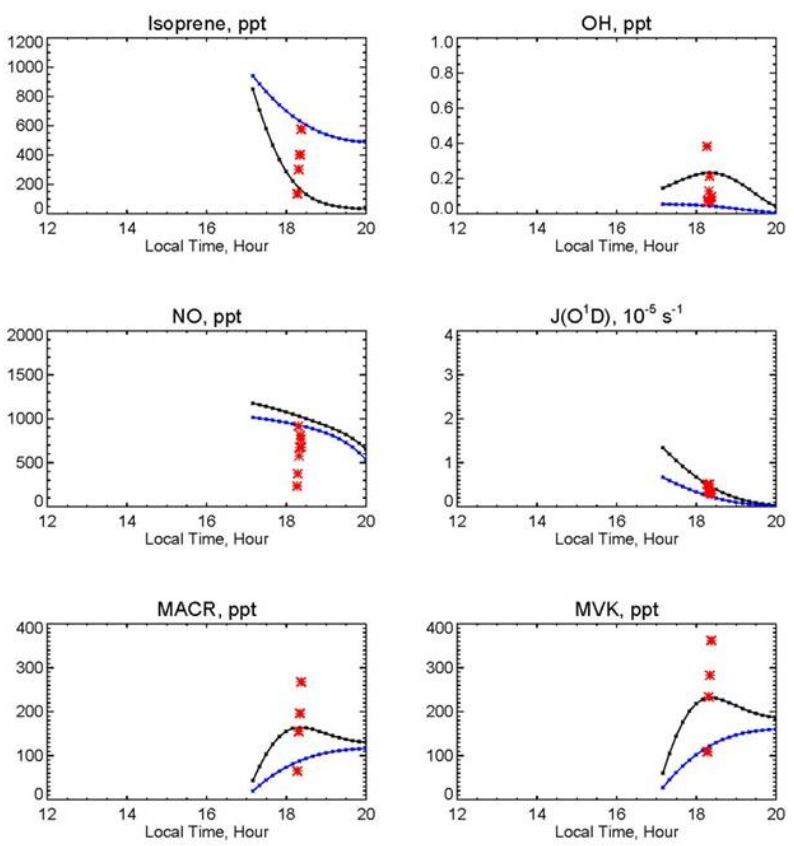

Fig. 6. LaRC DSS model results following injection of $1 \mathrm{ppbv}$ isoprene and $1.5 \mathrm{ppbv} \mathrm{NO}_{\mathrm{x}}$ into the boundary layer and shows the predicted (model) and measurement (red points) results for a number of species if the injection took place at (a) 15:00 $\mathrm{h}$ local sun time, i.e. $3.5 \mathrm{~h}$ before the event was observed, and (b) 17:00 h local sun time, i.e. $1.5 \mathrm{~h}$ before the event was observed. For each case, the model was run forward with clear-sky J-values (black trace) and then with J-values decreased by a factor of 2 (blue trace). See text for further discussion.

more rapid than predicted by photochemical age considerations. Since the chemical and physical environment within the updraft is very complex and changes rapidly (Barth et al., 2007), it is difficult to predict the physical and photochemical parameters that strongly affect the ultimate composition of the outflow. This will be the subject of a paper by Fried et al. (2012) which will include this particular event in their analysis.

\subsection{DSS modeling of event 1 - comparisons of modeled and measured mixing ratios}

Figure 7 shows comparisons of observations to the DSS (diurnal steady state) model for event 1 . The vertical dashed lines bracket the times in which the respective events were observed. The first panel shows isoprene and aircraft altitude as a function of time. The $\mathrm{OH}$-isoprene reaction proceeds principally by the addition of $\mathrm{OH}$ to the $\mathrm{C}=\mathrm{C}$ double bonds and yields, in addition to MACR and MVK, formaldehyde (other products are formed as well but not discussed here) which is a primary product but is also eventually formed several steps down the reaction chain. The measurements (blue) compare reasonably well with the model (black) for formaldehyde (panel 2), with only a modest increase predicted by the model during the event and the model showing slightly lower mixing ratios. As the $\mathrm{CH}_{2} \mathrm{O}$ backgrounds were stable during event 1 , we have the most confidence in the $\mathrm{CH}_{2} \mathrm{O}$ measurements during this period compared to the measurements before and after this event where the backgrounds were oscillating somewhat. The model results of MVK and MACR (panel 3) also follow the measurements reasonably well, with the measurements slightly enhanced relative to the model. In this case, the lower model-predicted carbonyls may be due to the lack of direct emissions in the model. The relative amounts of the isoprene oxidation products, MVK, MACR, and $\mathrm{CH}_{2} \mathrm{O}$ are better understood by considering the processing of these species: Loss of $\mathrm{CH}_{2} \mathrm{O}$ is dominated by photolysis (almost 90\%), which is uniform before and during the convection event, giving a lifetime of $\approx 2 \mathrm{~h}$ for $\mathrm{CH}_{2} \mathrm{O}$ throughout. Loss of MVK and MACR is dominated by reaction with $\mathrm{OH}$, which is suppressed within the high isoprene event, thus increasing the lifetime from $\approx 2 \mathrm{~h}$ outside the isoprene plume to $5-8 \mathrm{~h}$ during the high isoprene event.

Panels 4 and 5 show $\mathrm{OH}$ and $\mathrm{HO}_{2}$, respectively. Similar trends are observed for the data and model but there is a persistent but modest model over-prediction relative to the ATHOS data. $[\mathrm{OH}]$ is depressed during the event. The model values are within the uncertainty of the NCAR CIMS measurements for $\mathrm{HO}_{2}$, where data are available. This is interesting because a good deal of recent work has focused on discrepancies of modeled and measured $\mathrm{HO}_{\mathrm{x}}$ in isoprene-rich and $\mathrm{NO}_{\mathrm{x}}$-poor environments (excess $\mathrm{HO}_{\mathrm{x}}$ in measurements 

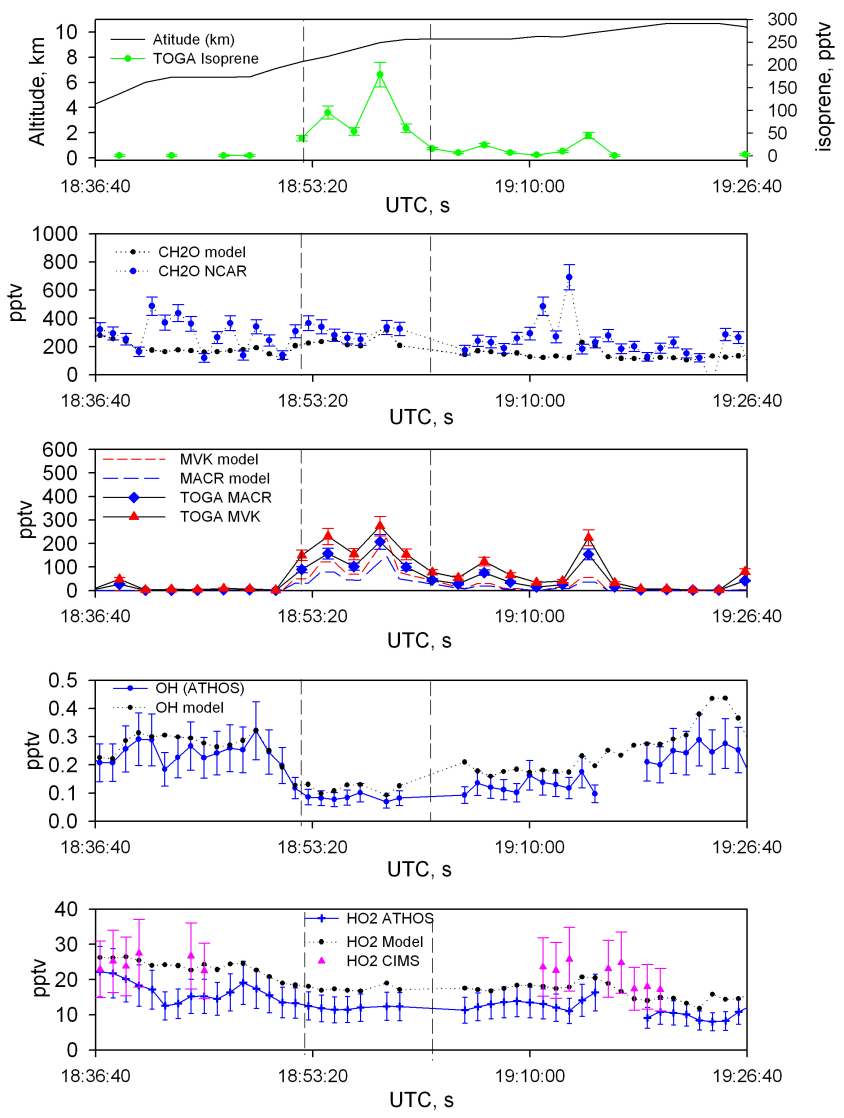

Fig. 7. Time series plots of measurement and LaRC DSS model results for event 1 . The bars represent the measurement uncertainties.

relative to models using standard chemistry) and new mechanisms of isoprene oxidation involving $\mathrm{OH}$-recycling mechanisms have been invoked to bring the models into better agreement with measurements (e.g. Peeters et al., 2009; Archibald et al., 2011). In this case, in which we use standard chemistry, there is not a continuous flux of isoprene into the system so recycling is inherently limited.

Comparisons of observations to the DSS model for event 2 were deemed not valid because of the rapidly changing chemical and physical environment in the updraft, precluding a steady-state condition.

\subsection{Chemistry following the event - effect on $\mathrm{HO}_{x}$, ozone, and nitrogen-containing compounds}

Recall that event 1 (Fig. 4a) exhibited high values of isoprene $(\approx 200 \mathrm{pptv})$ and isoprene oxidation products (MVK $+\mathrm{MACR} \approx 500$ pptv) at altitude but relatively low $\mathrm{NO}_{\mathrm{x}}$ $(\approx 50$ pptv). Event 1 occurred at noon local time while event 2 occurred later in the afternoon. For the purpose of this discussion and for a direct comparison of the evolution of the convective events with and without lightning, we consider events occurring at noon since convective events can occur anytime but most commonly occur from midday to later in the afternoon.

The first approach utilized the LaRC box model, run in its Lagrangian mode. The model was first initialized to a background DSS state using measurements obtained from the non-perturbed UT during the flight on 4 July $\left(\mathrm{NO}_{\mathrm{x}}=\right.$ $\left.50 \mathrm{pptv}, \mathrm{CO}=129 \mathrm{ppbv}, \mathrm{O}_{3}=76 \mathrm{ppbv}\right)$. After initialization, constraints are relaxed and the model predicts the chemical evolution of both radical species and their precursors. For the low $\mathrm{NO}_{\mathrm{x}}$ background scenario, the Lagrangian model proceeds with no additional adjustments. For the high $\mathrm{NO}_{\mathrm{x}}$ background scenario, $\mathrm{NO}_{\mathrm{x}}$ equal to $1500 \mathrm{pptv}$ is introduced at the beginning of the run as a non-equilibrium injection of lightning $\mathrm{NO}_{\mathrm{x}}$. A second run for each scenario introduces an additional injection of $1 \mathrm{ppb}$ isoprene at the beginning of the Lagrangian run. Figure 8a shows results for the background $\mathrm{NO}_{\mathrm{x}}$ condition; Fig. 8b shows results for the "lightning $\mathrm{NO}_{\mathrm{x}}$ " condition (same as Fig. 8a except $\mathrm{NO}_{\mathrm{x}}=1500$ pptv). In each illustrative case, $1 \mathrm{ppbv}$ of isoprene is "injected" at altitude $(11 \mathrm{~km})$ and the chemical evolution (black trace) is followed for $50 \mathrm{~h}$. Also shown in the figure is the chemical evolution (blue trace) under the same scenarios but without any isoprene.

Examining the low $\mathrm{NO}_{\mathrm{x}}$ scenario (Fig. 8a), we see that when isoprene is injected at $1 \mathrm{ppbv}$ (red trace) and followed for $50 \mathrm{~h}$, it takes approximately $30 \mathrm{~h}$ for isoprene to return to near-background levels. A diurnal pattern can be seen in this plot since little oxidation takes place during the night. The next panel down shows the model results for the first generation products MVK, MACR, and the second generation product, methyl glyoxal (MGLY). MVK and MACR build up to $\approx 100 \mathrm{pptv}$ and still persist $50 \mathrm{~h}$ later. These species are longer-lived than isoprene due to their significantly smaller reaction rate constants with $\mathrm{OH}$ compared to isoprene. MGLY is formed as well but the levels are very low. MGLY, despite its comparatively low yield from isoprene oxidation, is of interest because it can have a significant impact on the $\mathrm{HO}_{\mathrm{x}}$ budget as a result of its high photolysis rate which yields $\mathrm{CH}_{3} \mathrm{C}(\mathrm{O}) \mathrm{OO}$ and $\mathrm{HCO}$ radicals. In the absence of isoprene injection (blue trace), the model shows very low mixing ratios of MVK, MACR, and MGLY, since these products result only from isoprene oxidation. The third panel down shows formaldehyde. The pulse of isoprene results in a modest increase of formaldehyde. The blue trace shows that formaldehyde is present in the absence of isoprene because it results from the oxidation of many VOCs. There is a significant impact on the $\mathrm{OH}$ radical resulting from scavenging by the high isoprene levels, as shown by the difference between the red and blue traces. This serves to slow down the chemistry, leading to long lifetimes for MVK, MACR, etc. In this low $\mathrm{NO}_{\mathrm{x}}$ case (absence of lightning), the little NO that is available is suppressed following the pulse as there is some formation of PANs (not shown) via production of $\mathrm{RC}(\mathrm{O}) \mathrm{O}_{2}$ radicals and concomitantly various organic nitrates are produced, partially sequestering the available NO. 

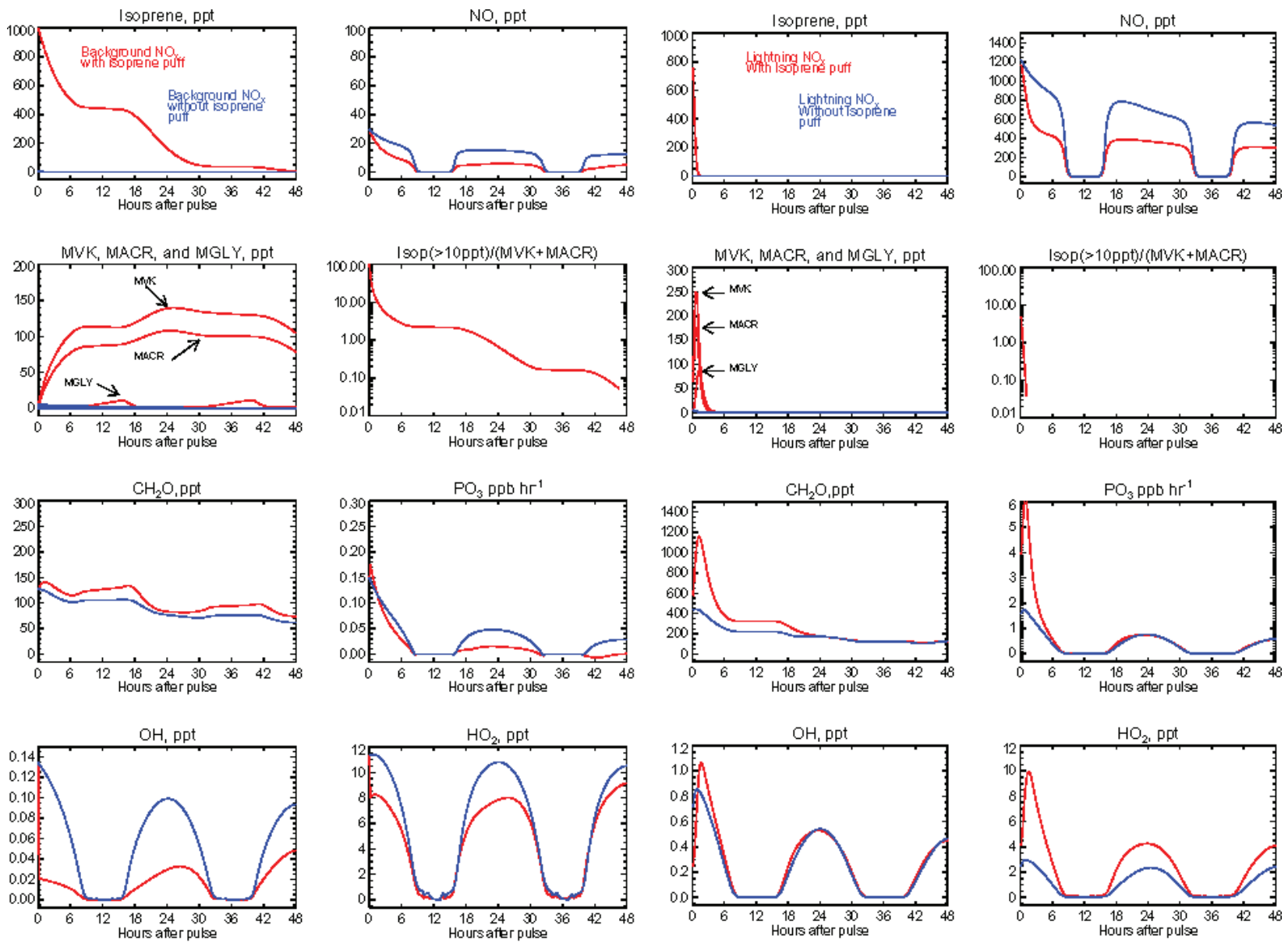

(a)
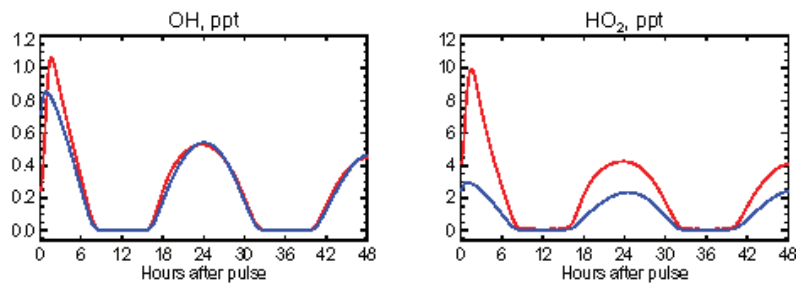

(b)

Fig. 8. Langrangian model simulation for the expected chemical evolution for selected key species with (red trace) and without (blue trace) injection of $1 \mathrm{ppbv}$ isoprene in the (a) low $\mathrm{NO}_{\mathrm{x}}\left(\right.$ no $\left.\mathrm{LNO}_{\mathrm{x}}\right)$ condition and (b) the high $\mathrm{NO}_{\mathrm{x}}\left(\mathrm{LNO}_{\mathrm{x}}\right)$ condition.

The ratio of isoprene to MVK + MACR changes over the course of $50 \mathrm{~h}$ from being dominated by isoprene (fresh emissions) to being dominated by the reaction products. Recall from the actual event 1 that when the air mass was intercepted by the DC-8, the ratio had already switched in favor of higher mixing ratios of reaction products relative to isoprene indicating an aged air-mass. There is little ozone production from the puff of isoprene in the background $\mathrm{NO}_{\mathrm{x}}$ regime and little effect is seen on $\mathrm{HO}_{2}$ levels.

In contrast to the low $\mathrm{NO}_{\mathrm{x}}$ scenario, the high $\mathrm{NO}_{\mathrm{x}}$ case demonstrates different behavior. Similar to Fig. 8a, the red trace in Fig. $8 \mathrm{~b}$ follows the behavior for $50 \mathrm{~h}$ of chemical species of interest, this time with $1 \mathrm{ppbv}$ of $\mathrm{LNO}_{\mathrm{x}}$ and $1 \mathrm{ppbv}$ of isoprene "injected" to mimic the high $\mathrm{NO}_{\mathrm{x}}$ lightning case. The blue trace shows the chemical behavior of the simulated air mass with $\mathrm{LNO}_{\mathrm{x}}$, but in the absence of isoprene. It is interesting to contrast the behavior of isoprene in Fig. 8b with the low $\mathrm{NO}_{\mathrm{x}}$ case in Fig. 8a. In the high $\mathrm{NO}_{\mathrm{x}}$ scenario, the lifetime of isoprene is reduced dramatically as a consequence of $\mathrm{NO}_{\mathrm{x}}-\mathrm{HO}_{\mathrm{x}}$ chemistry and oxidation mecha- nisms that under these conditions (with isoprene and other reactants present such as $\mathrm{CO}$, methane and other VOCs) produce net $\mathrm{HO}_{\mathrm{x}}$. Because of the increased $\mathrm{OH}$, there is a large spike in MACR, MVK, and MGLY as isoprene is rapidly oxidized. However, MVK and MACR lifetimes are also considerably shortened such that over approximately four hours these species have mixing ratios close to zero. MGLY is also short-lived but its lifetime is primarily controlled by photolysis. Similarly, formaldehyde shows a large increase initially, but persists longer than MVK, MACR, and MGLY principally because formaldehyde is formed from subsequent reactions of secondary and tertiary products further down the isoprene oxidation sequence. The persistence of formaldehyde after 30 to $50 \mathrm{~h}$ is the result of ongoing oxidation of VOCs other than isoprene as is clear by comparing the red with the blue trace. This is consistent with experimental results from Fried et al. (2008) which showed that the influence of upper tropospheric convection of $\mathrm{CH}_{2} \mathrm{O}$ precursors can persist as long as 1 week in the presence of $\mathrm{LNO}_{\mathrm{x}}$ of $1 \mathrm{ppbv}$. The $\mathrm{OH}$ radical is reduced initially due to scavenging 
by isoprene but then, as discussed above, the oxidation chemistry ensues yielding increased $\mathrm{OH}$. The $\mathrm{OH}$ is elevated during the second day as well, principally the result of formaldehyde (which is still in excess over background levels) photolysis. For NO, the scenario with high isoprene shows that it is reduced compared to the zero isoprene scenario. This is because isoprene oxidation results in enhanced formation of $\mathrm{PAN}$ via production of $\mathrm{CH}_{3} \mathrm{C}(\mathrm{O}) \mathrm{O}_{2}$ and various nitrates which effectively sequester the $\mathrm{NO}_{\mathrm{x}}$ at the cold temperatures of the upper tropospheric outflow. This is discussed further below. The second panel down on the right in Fig. 8b shows the isoprene/(MVK + MACR) ratio which in this case approaches zero after a few hours because of isoprene's short lifetime. The impact on $\mathrm{HO}_{2}$ is prolonged and coincides with the decrease in $\mathrm{NO}_{\mathrm{x}}$, relative to the no isoprene condition as discussed above; long-term, differences in $\mathrm{NO}$ and $\mathrm{HO}_{2}$ offset, yielding near equivalent rates of ozone production after the first few hours. Formaldehyde has the largest impact on $\mathrm{HO}_{2}$ but MGLY initially has a significant impact as well - up to $60 \%$ that of formaldehyde at its maximum which occurs approximately one hour after the pulse if we assume unity yields of $\mathrm{HO}_{2}$ from each of the first generation $\mathrm{CH}_{3} \mathrm{C}(\mathrm{O}) \mathrm{OO}$ and $\mathrm{HCO}$ radicals. However, under the high $\mathrm{NO}_{\mathrm{x}}$ conditions here, some significant fraction of $\mathrm{CH}_{3} \mathrm{C}(\mathrm{O}) \mathrm{OO}$ will be tied up as PAN, reducing the yield of $\mathrm{HO}_{2}$ from MGLY photolysis to less than two which, in turn, reduces its impact on $\mathrm{HO}_{\mathrm{x}}$.

Figure 9 shows in more detail the chemical evolution of the nitrogen-containing species and ozone production in the high $\mathrm{NO}_{\mathrm{x}}\left(\mathrm{LNO}_{\mathrm{x}}\right)$ scenario. In the presence of isoprene, $\mathrm{NO}_{\mathrm{x}}$ is reduced due to the formation of isoprene nitrates and PANs (The PANs here consist of PAN, PPN, and MPAN), and $\mathrm{CH}_{3} \mathrm{O}_{2} \mathrm{NO}_{2}$ as the total $\mathrm{NO}_{\mathrm{y}}$ remains constant. The $\mathrm{NO}_{\mathrm{x}}$ difference between the two simulations slowly equilibrates with the production of nitric acid $\left(\mathrm{HNO}_{3}\right)$. There is a significant difference in net ozone production only in the first few hours but it is vigorous enough to result in a cumulative difference in ozone of $10 \mathrm{ppbv}$ (lower panels).

When isoprene is present under lightning $\mathrm{NO}_{\mathrm{x}}$ conditions, it dominates the chemistry in the outflow. No other species, including the peroxides, contribute significantly to the radical pool under these conditions.

\section{Conclusions}

During ARCTAS-B, vertical profiles of a number of species indicated that summertime convection is important in redistributing both long-lived and short-lived species throughout the troposphere over Canada. A significant number of individual convective outflow events in the UT were identified by enhanced mixing ratios of organic species relative to background conditions. Several dramatic events were observed in which isoprene and its oxidation products were detected at hundreds of pptv at altitudes higher than $8 \mathrm{~km}$. Two events
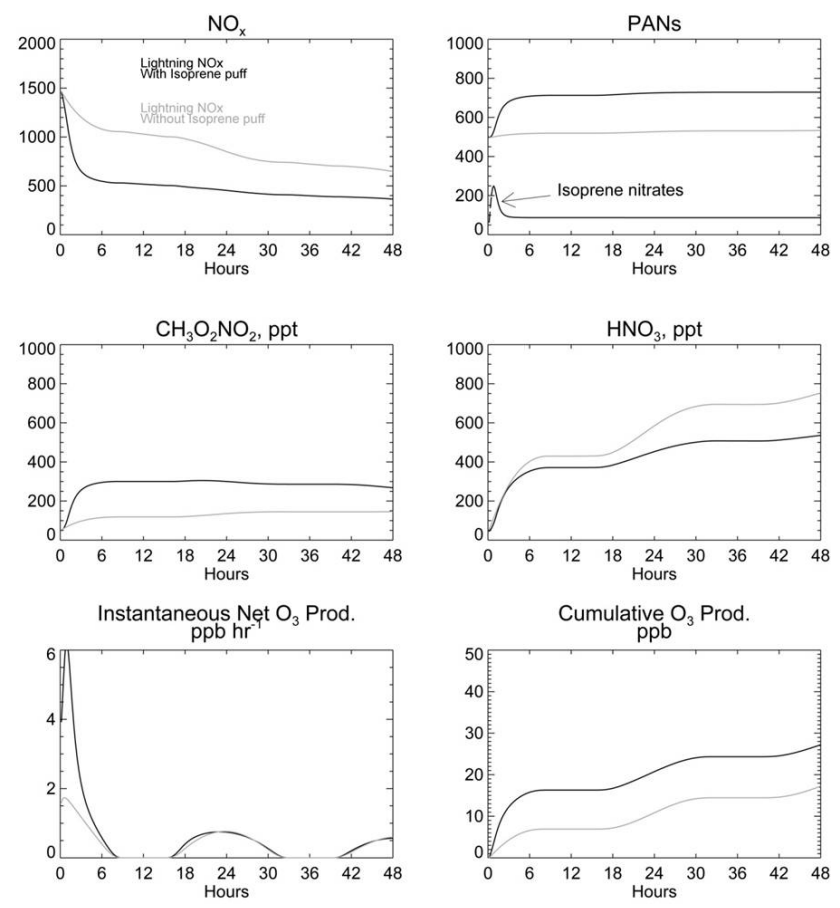

Fig. 9. Langrangian model simulation for the expected chemical evolution for key nitrogen containing species injection of $1 \mathrm{ppbv}$ isoprene in the high $\mathrm{NO}_{\mathrm{x}}\left(\mathrm{LNO}_{\mathrm{x}}\right)$ condition.

were studied in detail, both of which had isoprene and isoprene reaction products associated with them; one had no lightning $\mathrm{NO}_{\mathrm{x}}$ and another had substantial lightning $\mathrm{NO}_{\mathrm{x}}$ associated with it. The impact of the convective events on the upper tropospheric chemistry was assessed using the NASA LaRC model in the DSS and Lagrangian implementations.

When convective storms transport isoprene from the boundary layer to the UT under low $\mathrm{NO}_{\mathrm{x}}$ conditions $(<100$ pptv), first generation oxidation products persist for several days owing in part to the scavenging of the $\mathrm{OH}$ radical by isoprene. The overall impact is modest in terms of the amounts of PAN, ozone, and formaldehyde that are produced. The measurements and the DSS model agreed well under these relatively high-isoprene, low- $\mathrm{NO}_{\mathrm{x}}$ conditions. Conversely, when convective storms transport isoprene from the boundary layer to the UT and lightning $\mathrm{NO}_{\mathrm{x}}$ is present, there is a large effect on the expected ensuing chemistry. The model predicts a dominant impact from isoprene on $\mathrm{HO}_{\mathrm{x}}$ and nitrogen-containing species; the relative contribution from other potential $\mathrm{HO}_{\mathrm{x}}$ sources such as peroxides is insignificant. The isoprene is quickly reacted resulting in primary and secondary products, including formaldehyde and MGLY. The perturbation also results in the enhanced production of PAN compounds via production of $\mathrm{RC}(\mathrm{O}) \mathrm{O}_{2}$ radicals. PANs persist because of the cold temperatures of the UT, resulting in a large change in the $\mathrm{NO}_{\mathrm{x}}$ mixing ratios compared to the case in which no isoprene is convected. During the first few 
hours following the convective event, photolysis of formaldehyde and MGLY impacts the $\mathrm{HO}_{\mathrm{x}}$ budget and results in a change to the $\mathrm{OH} / \mathrm{HO}_{2}$ ratio. Ozone production is substantial in the first few hours as well and results in a net ozone enhancement of approximately $10 \mathrm{ppbv}$ based on our modeled scenario. While convection of isoprene along with lightning $\mathrm{NO}_{\mathrm{x}}$ emissions are expected to be more prevalent in the tropics (Aschmann et al., 2009; Marecal et al., 2006), these events are likely to be fairly common in the US, Canada and other mid-latitude regions during the warm season. Future measurement and modeling studies of this process will be valuable for establishing the regional and global impact on UT chemistry.

Acknowledgements. The authors thank the crew and support team for the NASA DC-8 aircraft, and Mary Barth, Frank Flocke and John Orlando for helpful comments and discussion. The authors gratefully acknowledge the financial support of NASA (Grant No. X08AD33G). PTR-MS measurements were supported by the Austrian Research Promotion Agency (FFG-ALR) and the Tiroler Zukunftstiftung, and were carried out with the help/support of M. Graus, A. Hansel and T. D. Maerk. The National Center for Atmospheric Research is sponsored by the National Science Foundation. Any opinions, findings and conclusions or recommendations expressed in the publication are those of the authors and do not necessarily reflect the views of the National Science Foundation.

Edited by: J. W. Bottenheim

\section{References}

Apel, E. C., Riemer, D. D., Hills, A., Baugh, W., Orlando, J., Faloona, I., Tan, D., Brune, W., Lamb, B., Westberg, H., Carroll, M. A., Thornberry, T., and Geron, C. D.: Measurement and interpretation of isoprene fluxes and isoprene, methacrolein, and methyl vinyl ketone mixing ratios at the PROPHET site during the 1998 intensive, J. Geophys. Res., 107, 4034, doi:10.1029/2000jd000225, 2002.

Apel, E. C., Emmons, L. K., Karl, T., Flocke, F., Hills, A. J., Madronich, S., Lee-Taylor, J., Fried, A., Weibring, P., Walega, J., Richter, D., Tie, X., Mauldin, L., Campos, T., Weinheimer, A., Knapp, D., Sive, B., Kleinman, L., Springston, S., Zaveri, R., Ortega, J., Voss, P., Blake, D., Baker, A., Warneke, C., Welsh-Bon, D., de Gouw, J., Zheng, J., Zhang, R., Rudolph, J., Junkermann, W., and Riemer, D. D.: Chemical evolution of volatile organic compounds in the outflow of the Mexico City Metropolitan area, Atmos. Chem. Phys., 10, 2353-2375, doi:10.5194/acp-10-23532010, 2010.

Archibald, A. T., Levine, J. G., Abraham, N. L., Cooke, M. C., Edwards, P. M., Heard, D. E., Jenkin, M. E., Karunaharan, A., Pike, R. C., Monks, P. S., Shallcross, D. E., Telford, P. J., Whalley, L. K., and Pyle, J. A.: Impacts of $\mathrm{HO}_{\mathrm{x}}$ regeneration and recycling in the oxidation of isoprene: Consequences for the composition of past, present and future atmospheres, Geophys. Res. Lett., 38, L05804, doi:10.1029/2010g1046520, 2011.

Aschmann, J., Sinnhuber, B.-M., Atlas, E. L., and Schauffler, S. M.: Modeling the transport of very short-lived substances into the tropical upper troposphere and lower stratosphere, Atmos. Chem. Phys., 9, 9237-9247, doi:10.5194/acp-9-9237-2009, 2009.

Atkinson, R.: Gas-phase tropospheric chemistry of organiccompounds, J. Phys. Chem. Ref. Data, R1-\&, 1994.

Barth, M. C., Kim, S. W., Skamarock, W. C., Stuart, A. L., Pickering, K. E., and Ott, L. E.: Simulations of the redistribution of formaldehyde, formic acid, and peroxides in the 10 July 1996 Stratospheric-Tropospheric Experiment: Radiation, Aerosols, and Ozone Deep Convection Storm, J. Geophsy. Res., 112, D13310, doi:10.1029/2006jd008046, 2007.

Bertman, S. B., Roberts, J. M., Parrish, D. D., Buhr, M. P., Goldan, P. D., Kuster, W. C., Fehsenfeld, F. C., Montzka, S. A., and Westberg, H.: Evolution of alkyl nitrates with air-mass age, J. Geophys. Res., 100, 22805-22813, 1995.

Bertram, T. H., Perring, A. E., Wooldridge, P. J., Crounse, J. D., Kwan, A. J., Wennberg, P. O., Scheuer, E., Dibb, J., Avery, M., Sachse, G., Vay, S. A., Crawford, J. H., McNaughton, C. S., Clarke, A., Pickering, K. E., Fuelberg, H., Huey, G., Blake, D. R., Singh, H. B., Hall, S. R., Shetter, R. E., Fried, A., Heikes, B. G., and Cohen, R. C.: Direct measurements of the convective recycling of the upper troposphere, Science, 315, 816-820, doi:10.1126/science.1134548, 2007.

Brune, W. H., Faloona, I. C., Tan, D., Weinheimer, A. J., Campos, T., Ridley, B. A., Vay, S. A., Collins, J. E., Sachse, G. W., Jaegle, L., and Jacob, D. J.: Airborne in-situ $\mathrm{OH}$ and $\mathrm{HO}_{2}$ observations in the cloud-free troposphere and lower stratosphere during success, Geophys. Res. Lett., 25, 1701-1704, 1998.

Brune, W. H., Tan, D., Faloona, I. F., Jaegle, L., Jacob, D. J., Heikes, B. G., Snow, J., Kondo, Y., Shetter, R., Sachse, G. W., Anderson, B., Gregory, G. L., Vay, S., Singh, H. B., Davis, D. D., Crawford, J. H., and Blake, D. R.: $\mathrm{OH}$ and $\mathrm{HO}_{2}$ chemistry in the North Atlantic free troposphere, Geophys. Res. Lett., 26, 3077-3080, 1999.

Cantrell, C. A., Edwards, G. D., Stephens, S., Mauldin, R. L., Zondlo, M. A., Kosciuch, E., Eisele, F. L., Shetter, R. E., Lefer, B. L., Hall, S., Flocke, F., Weinheimer, A., Fried, A., Apel, E., Kondo, Y., Blake, D. R., Blake, N. J., Simpson, I. J., Bandy, A. R., Thornton, D. C., Heikes, B. G., Singh, H. B., Brune, W. H., Harder, H., Martinez, M., Jacob, D. J., Avery, M. A., Barrick, J. D., Sachse, G. W., Olson, J. R., Crawford, J. H., and Clarke, A. D.: Peroxy radical behavior during the transport and chemical evolution over the Pacific (TRACE-P) campaign as measured aboard the NASA P-3b aircraft, J. Geophys. Res., 108, 8797, doi:10.1029/2003jd003674, 2003.

Carroll, M. A., Ridley, B. A., Montzka, D. D., Hubler, G., Walega, J. G., Norton, R. B., Huebert, B. J., and Grahek, F. E.: Measurements of nitric-oxide and nitrogen-dioxide during the MaunaLoa-Observatory Photochemistry Experiment, J. Geophys. Res, 97, 10361-10374, 1992.

Chatfield, R. B. and Crutzen, P. J.: Sulfur-dioxide in remote oceanic air - cloud transport of reactive precursors, J. Geophys. Res, 89, 7111-7132, 1984.

Chuong, B. and Stevens, P.: Measurements of the kinetics of the $\mathrm{OH}$-initiated oxidation of methyl vinyl ketone and methacrolein, Int. J. Chem. Kinet., 36, 12-25, doi:10.1002/kin.10167, 2004.

Cohan, D. S., Schultz, M. G., Jacob, D. J., Heikes, B. G., and Blake, D. R.: Convective injection and photochemical decay of peroxides in the tropical upper troposphere: Methyl iodide as a tracer of marine convection, J. Geophys. Res., 104, 5717-5724, 1999. 
Collins, W. J., Stevenson, D. S., Johnson, C. E., and Derwent, R. G.: Role of convection in determining the budget of odd hydrogen in the upper troposphere, J. Geophys. Res., 104, 26927-26941, 1999.

Colman, J. J., Swanson, A. L., Meinardi, S., Sive, B. C., Blake, D. R., and Rowland, F. S.: Description of the analysis of a wide range of volatile organic compounds in whole air samples collected during PEM-TROPICS A and B, Anal. Chem., 73, 37233731, 2001.

Colomb, A., Williams, J., Crowley, J., Gros, V., Hofmann, R., Salisbury, G., Klupfel, T., Kormann, R., Stickler, A., Forster, C., and Lelieveld, J.: Airborne measurements of trace organic species in the upper troposphere over Europe: The impact of deep convection, Environ. Chem., 3, 244-259, doi:10.1071/en06020, 2006.

Cooper, O. R., Trainer, M., Thompson, A. M., Oltmans, S. J., Tarasick, D. W., Witte, J. C., Stohl, A., Eckhardt, S., Lelieveld, J., Newchurch, M. J., Johnson, B. J., Portmann, R. W., Kalnajs, L., Dubey, M. K., Leblanc, T., McDermid, I. S., Forbes, G., Wolfe, D., Carey-Smith, T., Morris, G. A., Lefer, B., Rappengluck, B., Joseph, E., Schmidlin, F., Meagher, J., Fehsenfeld, F. C., Keating, T. J., Van Curen, R. A., and Minschwaner, K.: Evidence for a recurring eastern North America upper tropospheric ozone maximum during summer, J. Geophys. Res., 112, D23304, doi:10.1029/2007jd008710, 2007.

Crawford, J., Davis, D., Olson, J., Chen, G., Liu, S., Gregory, G., Barrick, J., Sachse, G., Sandholm, S., Heikes, B., Singh, H., and Blake, D.: Assessment of upper tropospheric $\mathrm{HO}_{\mathrm{x}}$ sources over the tropical Pacific based on NASA GTE/PEM data: Net effect on $\mathrm{HO}_{\mathrm{x}}$ and other photochemical parameters, J. Geophys. Res., 104, 16255-16273, 1999.

Crounse, J. D., McKinney, K. A., Kwan, A. J., and Wennberg, P. O.: Measurement of gas-phase hydroperoxides by chemical ionization mass spectrometry, Anal. Chem., 78, 6726-6732, doi:10.1021/ac0604235, 2006.

de Gouw, J. and Warneke, C.: Measurements of volatile organic compounds in the Earth's atmosphere using proton-transferreaction mass spectrometry, Mass Spec. Rev., 26, 223-257, doi:10.1002/mas.20119, 2007.

de Gouw, J. A., Goldan, P. D., Warneke, C., Kuster, W. C., Roberts, J. M., Marchewka, M., Bertman, S. B., Pszenny, A. A. P., and Keene, W. C.: Validation of Proton Transfer ReactionMass Spectrometry (PTR-MS) measurements of gas-phase organic compounds in the atmosphere during the New England Air Quality Study (NEAQS) in 2002, J. Geophys. Res., 108, 4682, doi:10.1029/2003jd003863, 2003.

DeCaria, A. J., Pickering, K. E., Stenchikov, G. L., and Ott, L. E.: Lightning-generated $\mathrm{NO}_{\mathrm{x}}$ and its impact on tropospheric ozone production: A three-dimensional modeling study of a Stratosphere-Troposphere Experiment: Radiation, Aerosols and Ozone (STERAO-A) thunderstorm, J. Geophys. Res., 110, D14303, doi:10.1029/2004jd005556, 2005.

Dickerson, R. R., Huffman, G. J., Luke, W. T., Nunnermacker, L. J., Pickering, K. E., Leslie, A. C. D., Lindsey, C. G., Slinn, W. G. N., Kelly, T. J., Daum, P. H., Delany, A. C., Greenberg, J. P., Zimmerman, P. R., Boatman, J. F., Ray, J. D., and Stedman, D. H.: Thunderstorms - an important mechanism in the transport of air-pollutants, Science, 235, 460-464, 1987.

Diskin, G. S., Podolske, J. R., Sachse, G. W., and Slate, T. A.: Open-path airborne tunable diode laser hygrometer, in: Diode lasers and applications in atmospheric sensing, edited by: Fried, A., Proceedings of the Society Of Photo-Optical Instrumentation Engineers (SPIE), 196-204, 2002.

Faloona, I. C., Tan, D., Lesher, R. L., Hazen, N. L., Frame, C. L., Simpas, J. B., Harder, H., Martinez, M., Di Carlo, P., Ren, X. R., and Brune, W. H.: A laser-induced fluorescence instrument for detecting tropospheric $\mathrm{OH}$ and $\mathrm{HO}_{2}$ : Characteristics and calibration, J. Atmos. Chem., 47, 139-167, 2004.

Fried, A., Olson, J. R., Walega, J. G., Crawford, J. H., Chen, G., Weibring, P., Richter, D., Roller, C., Tittel, F., Porter, M., Fuelberg, H., Halland, J., Bertram, T. H., Cohen, R. C., Pickering, K., Heikes, B. G., Snow, J. A., Shen, H. W., O'Sullivan, D. W., Brune, W. H., Ren, X. R., Blake, D. R., Blake, N., Sachse, G., Diskin, G. S., Podolske, J., Vay, S. A., Shetter, R. E., Hall, S. R., Anderson, B. E., Thornhill, L., Clarke, A. D., McNaughton, C. S., Singh, H. B., Avery, M. A., Huey, G., Kim, S., and Millet, D. B.: Role of convection in redistributing formaldehyde to the upper troposphere over North America and the North Atlantic during the summer 2004 INTEX campaign, J. Geophys. Res., 113, D17306, doi:10.1029/2007jd009760, 2008.

Friedli, H. R., Atlas, E., Stroud, V. R., Giovanni, L., Campos, T., and Radke, L. F.: Volatile organic trace gases emitted from North American wildfires, Global Biogeochem. Cy., 15, 435452, 2001.

Goldstein, A. H. and Galbally, I. E.: Known and unexplored organic constituents in the Earth's atmosphere, Environ. Sci. Tech., 41, 1514-1521, 2007.

Guenther, A., Karl, T., Harley, P., Wiedinmyer, C., Palmer, P. I., and Geron, C.: Estimates of global terrestrial isoprene emissions using MEGAN (Model of Emissions of Gases and Aerosols from Nature), Atmos. Chem. Phys., 6, 3181-3210, doi:10.5194/acp-63181-2006, 2006.

Hornbrook, R. S., Crawford, J. H., Edwards, G. D., Goyea, O., Mauldin III, R. L., Olson, J. S., and Cantrell, C. A.: Measurements of tropospheric $\mathrm{HO}_{2}$ and $\mathrm{RO}_{2}$ by oxygen dilution modulation and chemical ionization mass spectrometry, Atmos. Meas. Tech., 4, 735-756, doi:10.5194/amt-4-735-2011, $2011 \mathrm{a}$.

Hornbrook, R. S., Blake, D. R., Diskin, G. S., Fried, A., Fuelberg, H. E., Meinardi, S., Mikoviny, T., Richter, D., Sachse, G. W., Vay, S. A., Walega, J., Weibring, P., Weinheimer, A. J., Wiedinmyer, C., Wisthaler, A., Hills, A., Riemer, D. D., and Apel, E. C.: Observations of nonmethane organic compounds during ARCTAS - Part 1: Biomass burning emissions and plume enhancements, Atmos. Chem. Phys., 11, 11103-11130, doi:10.5194/acp11-11103-2011, 2011b.

Hudman, R. C., Jacob, D. J., Turquety, S., Leibensperger, E. M., Murray, L. T., Wu, S., Gilliland, A. B., Avery, M., Bertram, T. H., Brune, W., Cohen, R. C., Dibb, J. E., Flocke, F. M., Fried, A., Holloway, J., Neuman, J. A., Orville, R., Perring, A., Ren, X., Sachse, G. W., Singh, H. B., Swanson, A., and Wooldridge, P. J.: Surface and lightning sources of nitrogen oxides over the United States: Magnitudes, chemical evolution, and outflow, J. Geophys. Res., 112, 14, D12s05, doi:10.1029/2006jd007912, 2007.

Huntrieser, H., Schlager, H., Lichtenstern, M., Stock, P., Hamburger, T., Hller, H., Schmidt, K., Betz, H.-D., Ulanovsky, A., and Ravegnani, F.: Mesoscale convective systems observed during AMMA and their impact on the $\mathrm{NO}_{\mathrm{x}}$ and $\mathrm{O}_{3}$ budget over West Africa, Atmos. Chem. Phys., 11, 2503-2536, doi:10.5194/acp-11-2503-2011, 2011. 
Jacob, D. J., Crawford, J. H., Maring, H., Clarke, A. D., Dibb, J. E., Emmons, L. K., Ferrare, R. A., Hostetler, C. A., Russell, P. B., Singh, H. B., Thompson, A. M., Shaw, G. E., McCauley, E., Pederson, J. R., and Fisher, J. A.: The Arctic Research of the Composition of the Troposphere from Aircraft and Satellites (ARCTAS) mission: design, execution, and first results, Atmos. Chem. Phys., 10, 5191-5212, doi:10.5194/acp-10-5191-2010, 2010.

Jaegle, L., Jacob, D. J., Wennberg, P. O., Spivakovsky, C. M., Hanisco, T. F., Lanzendorf, E. J., Hintsa, E. J., Fahey, D. W., Keim, E. R., Proffitt, M. H., Atlas, E. L., Flocke, F., Schauffler, S., McElroy, C. T., Midwinter, C., Pfister, L., and Wilson, J. C.: Observed $\mathrm{OH}$ and $\mathrm{HO}_{2}$ in the upper troposphere suggest a major source from convective injection of peroxides, Geophys. Res. Lett., 24, 3181-3184, 1997.

Jaegle, L., Jacob, D. J., Brune, W. H., Tan, D., Faloona, I. C., Weinheimer, A. J., Ridley, B. A., Campos, T. L., and Sachse, G. W.: Sources of $\mathrm{HO}_{\mathrm{x}}$ and production of ozone in the upper troposphere over the United States, Geophys. Res. Lett., 25, 1709 $1712,1998$.

Jaegle, L., Jacob, D. J., Brune, W. H., and Wennberg, P. O.: Chemistry of $\mathrm{HO}_{\mathrm{x}}$ radicals in the upper troposphere, Atmos. Environ., 35, 469-489, 2001.

Karl, T. G., Christian, T. J., Yokelson, R. J., Artaxo, P., Hao, W. M., and Guenther, A.: The Tropical Forest and Fire Emissions Experiment: method evaluation of volatile organic compound emissions measured by PTR-MS, FTIR, and GC from tropical biomass burning, Atmos. Chem. Phys., 7, 5883-5897, doi:10.5194/acp-7-5883-2007, 2007.

Karl, T., Harley, P., Emmons, L., Thornton, B., Guenther, A., Basu, C., Turnipseed, A., and Jardine, K.: Efficient atmospheric cleansing of oxidized organic trace gases by vegetation, Science, 330, 816-819, doi:10.1126/science.1192534, 2010.

Kiley, C. M. and Fuelberg, H. E.: An examination of summertime cyclone transport processes during Intercontinental Chemical Transport Experiment (INTEX-A), J. Geophys. Res., 111, D24s06, doi:10.1029/2006jd007115, 2006.

Lindinger, W., Hansel, A., and Jordan, A.: On-line monitoring of volatile organic compounds at pptv levels by means of ProtonTransfer-Reaction Mass Spectrometry (PTR-MS) - medical applications, food control and environmental research, Int. J. Mass. Spec., 173, 191-241, 1998.

Marécal, V., Rivière, E. D., Held, G., Cautenet, S., and Freitas, S.: Modelling study of the impact of deep convection on the utls air composition - Part I: Analysis of ozone precursors, Atmos. Chem. Phys., 6, 1567-1584, doi:10.5194/acp-6-1567-2006, 2006

Martin, R. V., Jacob, D. J., Chance, K., Kurosu, T. P., Palmer, P. I., and Evans, M. J.: Global inventory of nitrogen oxide emissions constrained by space-based observations of $\mathrm{NO}_{2}$ columns, J. Geophys. Res., 108, 4537, doi:10.1029/2003jd003453, 2003.

Mauldin, R. L., Tanner, D. J., and Eisele, F. L.: Measurements of OH during Pem-Tropics A, J. Geophys. Res., 104, 5817-5827, doi:10.1029/98jd02305, 1999.

Millet, D. B., Guenther, A., Siegel, D. A., Nelson, N. B., Singh, H. B., de Gouw, J. A., Warneke, C., Williams, J., Eerdekens, G., Sinha, V., Karl, T., Flocke, F., Apel, E., Riemer, D. D., Palmer, P. I., and Barkley, M.: Global atmospheric budget of acetaldehyde: 3-D model analysis and constraints from in-situ and satellite observations, Atmos. Chem. Phys., 10, 3405-3425, doi:10.5194/acp-10-3405-2010, 2010.

Olson, J. R., Crawford, J. H., Davis, D. D., Chen, G., Avery, M. A., Barrick, J. D. W., Sachse, G. W., Vay, S. A., Sandholm, S. T., Tan, D., Brune, W. H., Faloona, I. C., Heikes, B. G., Shetter, R. E., Lefer, B. L., Singh, H. B., Talbot, R. W., and Blake, D. R.: Seasonal differences in the photochemistry of the South Pacific: A comparison of observations and model results from PEM-TROPICS A and B, J. Geophys. Res., 106, 32749-32766, 2001.

Olson, J. R., Crawford, J. H., Chen, G., Fried, A., Evans, M. J., Jordan, C. E., Sandholm, S. T., Davis, D. D., Anderson, B. E., Avery, M. A., Barrick, J. D., Blake, D. R., Brune, W. H., Eisele, F. L., Flocke, F., Harder, H., Jacob, D. J., Kondo, Y., Lefer, B. L., Martinez, M., Mauldin, R. L., Sachse, G. W., Shetter, R. E., Singh, H. B., Talbot, R. W., and Tan, D.: Testing fast photochemical theory during TRACE-P based on measurements of $\mathrm{OH}, \mathrm{HO}_{2}$, and $\mathrm{CH}_{2} \mathrm{O}$, J. Geophys. Res., 109, D15s10, doi:10.1029/2003jd004278, 2004.

Olson, J. R., Crawford, J. H., Chen, G., Brune, W. H., Faloona, I. C., Tan, D., Harder, H., and Martinez, M.: A reevaluation of airborne $\mathrm{HO}_{\mathrm{x}}$ observations from NASA field campaigns, J. Geophys. Res., 111, D10301, doi:10.1029/2005jd006617, 2006.

Paulot, F., Crounse, J. D., Kjaergaard, H. G., Kurten, A., St Clair, J. M., Seinfeld, J. H., and Wennberg, P. O.: Unexpected epoxide formation in the gas-phase photooxidation of isoprene, Science, 325, 730-733, doi:10.1126/science.1172910, 2009.

Peeters, J., Nguyen, T. L., and Vereecken, L.: $\mathrm{HO}_{\mathrm{x}}$ radical regeneration in the oxidation of isoprene, Phys. Chem. Chem. Phys., 11, 5935-5939, doi:10.1039/b908511d, 2009.

Perring, A. E., Bertram, T. H., Farmer, D. K., Wooldridge, P. J., Dibb, J., Blake, N. J., Blake, D. R., Singh, H. B., Fuelberg, H., Diskin, G., Sachse, G., and Cohen, R. C.: The production and persistence of $\Sigma \mathrm{RONO}_{2}$ in the Mexico City plume, Atmos. Chem. Phys., 10, 7215-7229, doi:10.5194/acp-10-7215-2010, 2010.

Pickering, K. E., Thompson, A. M., Dickerson, R. R., Luke, W. T., McNamara, D. P., Greenberg, J. P., and Zimmerman, P. R.: Model-calculations of tropospheric ozone production potential following observed convective events, J. Geophys. Res., 95, 14049-14062, 1990.

Pickering, K. E., Thompson, A. M., Scala, J. R., Tao, W. K., Dickerson, R. R., and Simpson, J.: Free tropospheric ozone production following entrainment of urban plumes into deep convection, J. Geophys. Res., 97, 17985-18000, 1992.

Poppe, D., Brauers, T., Dorn, H. P., Karl, M., Mentel, T., Schlosser, E., Tillmann, R., Wegener, R., and Wahner, A.: OHinitiated degradation of several hydrocarbons in the atmosphere simulation chamber SAPHIR, J. Atmos. Chem., 57, 203-214, doi:10.1007/s10874-007-9065-y, 2007.

Prather, M. J. and Jacob, D. J.: A persistent imbalance in $\mathrm{HO}_{\mathrm{x}}$ and $\mathrm{NO}_{\mathrm{x}}$ photochemistry of the upper troposphere driven by deep tropical convection, Geophys. Res. Lett., 24, 3189-3192, 1997.

Ren, X. R., Olson, J. R., Crawford, J. H., Brune, W. H., Mao, J. Q., Long, R. B., Chen, Z., Chen, G., Avery, M. A., Sachse, G. W., Barrick, J. D., Diskin, G. S., Huey, L. G., Fried, A., Cohen, R. C., Heikes, B., Wennberg, P. O., Singh, H. B., Blake, D. R., and Shetter, R. E.: $\mathrm{HO}_{\mathrm{x}}$ chemistry during INTEX-A 2004: Observation, model calculation, and comparison with previous studies, J. Geophys. Res., 113, D05310, doi:10.1029/2007jd009166, 2008. 
Ridley, B. A., Walega, J. G., Dye, J. E., and Grahek, F. E.: Distributions of $\mathrm{NO}, \mathrm{NO}_{\mathrm{x}}, \mathrm{NO}_{\mathrm{y}}, \mathrm{AND} \mathrm{O}_{3}$ to $12 \mathrm{~km}$ altitude during the summer monsoon season over New Mexico, J. Geophys. Res., 99, 25519-25534, 1994.

Ridley, B., Ott, L., Pickering, K., Emmons, L., Montzka, D., Weinheimer, A., Knapp, D., Grahek, F., Li, L., Heymsfield, G., McGill, M., Kucera, P., Mahoney, M. J., Baumgardner, D., Schultz, M., and Brasseur, G.: Florida thunderstorms: A faucet of reactive nitrogen to the upper troposphere, J. Geophys. Res., 109, D17305, doi:10.1029/2004jd004769, 2004.

Sachse, G. W., Collins, J. E., Hill, G. F., Wade, L. O., Burney, L. G., and Ritter, J. A.: Airborne tunable diode-laser sensor for high-precision concentration and flux measurements of carbonmonoxide and methane, in: Measurement of atmospheric gases, edited by: Schiff, H. I., Proceedings of the Society Of PhotoOptical Instrumentation Engineers (SPIE), 157-166, 1991.

Schumann, U. and Huntrieser, H.: The global lightning-induced nitrogen oxides source, Atmos. Chem. Phys., 7, 3823-3907, doi:10.5194/acp-7-3823-2007, 2007.

Shetter, R. E. and Muller, M.: Photolysis frequency measurements using actinic flux spectroradiometry during the PEM-TROPICS mission: Instrumentation description and some results, J. Geophys. Res., 104, 5647-5661, 1999.

Shindell, D. T., Levy, H., Schwarzkopf, M. D., Horowitz, L. W., Lamarque, J. F., and Faluvegi, G.: Multimodel projections of climate change from short-lived emissions due to human activities, J. Geophys. Res., 113, D11109, doi:10.1029/2007jd009152, 2008.

Simpson, I. J., Blake, N. J., Barletta, B., Diskin, G. S., Fuelberg, H. E., Gorham, K., Huey, L. G., Meinardi, S., Rowland, F. S., Vay, S. A., Weinheimer, A. J., Yang, M., and Blake, D. R.: Characterization of trace gases measured over Alberta oil sands mining operations: 76 speciated $\mathrm{C} 2 \mathrm{C} 10$ volatile organic compounds (VOCs), $\mathrm{CO}_{2}, \mathrm{CH}_{4}, \mathrm{CO}, \mathrm{NO}, \mathrm{NO}_{2}, \mathrm{NO}_{\mathrm{y}}, \mathrm{O}_{3}$ and $\mathrm{SO}_{2}$, Atmos. Chem. Phys., 10, 11931-11954, doi:10.5194/acp10-11931-2010, 2010.

Singh, H. B., Kanakidou, M., Crutzen, P. J., and Jacob, D. J.: High concentrations and photochemical fate of oxygenated hydrocarbons in the global troposphere, Nature, 378, 50-54, 1995.

Singh, H. B., Salas, L., Herlth, D., Kolyer, R., Czech, E., Avery, M., Crawford, J. H., Pierce, R. B., Sachse, G. W., Blake, D. R., Cohen, R. C., Bertram, T. H., Perring, A., Wooldridge, P. J., Dibb, J., Huey, G., Hudman, R. C., Turquety, S., Emmons, L. K., Flocke, F., Tang, Y., Carmichael, G. R., and Horowitz, L. W.: Reactive nitrogen distribution and partitioning in the North American troposphere and lowermost stratosphere, J. Geophys. Res., 112, D12s04, doi:10.1029/2006jd007664, 2007.
Snow, J. A., Heikes, B. G., Shen, H. W., O’Sullivan, D. W., Fried, A., and Walega, J.: Hydrogen peroxide, methyl hydroperoxide, and formaldehyde over North America and the North Atlantic, J. Geophys. Res., 112, D12s07, doi:10.1029/2006jd007746, 2007.

Stickler, A., Fischer, H., Williams, J., de Reus, M., Sander, R., Lawrence, M. G., Crowley, J. N., and Lelieveld, J.: Influence of summertime deep convection on formaldehyde in the middle and upper troposphere over Europe, J. Geophys. Res., 111, D14308, doi:10.1029/2005jd007001, 2006.

St. Clair, J. M., McCabe, D. C., Crounse, J. D., Steiner, U., and Wennberg, P. O.: Chemical ionization tandem mass spectrometer for the in situ measurement of methyl hydrogen peroxide, Rev. Sci. Instrum., 81, 094102, doi:10.1063/1.3480552, 2010.

Wang, C. and Prinn, R. G.: On the roles of deep convective clouds in tropospheric chemistry, J. Geophys. Res., 105, 22269-22297, 2000.

Weibring, P., Richter, D., Walega, J. G., Rippe, L., and Fried, A.: Difference frequency generation spectrometer for simultaneous multispecies detection, Optics Express, 18, 27670-27681, 2010.

Wennberg, P. O., Hanisco, T. F., Cohen, R. C., Stimpfle, R. M., Lapson, L. B., and Anderson, J. G.: In-situ measurements of $\mathrm{OH}$ and $\mathrm{HO}_{2}$ in the upper troposphere and stratosphere, J. Atmos. Sci., 52, 3413-3420, 1995.

Wennberg, P. O., Hanisco, T. F., Jaegle, L., Jacob, D. J., Hintsa, E. J., Lanzendorf, E. J., Anderson, J. G., Gao, R. S., Keim, E. R., Donnelly, S. G., Del Negro, L. A., Fahey, D. W., McKeen, S. A., Salawitch, R. J., Webster, C. R., May, R. D., Herman, R. L., Proffitt, M. H., Margitan, J. J., Atlas, E. L., Schauffler, S. M., Flocke, F., McElroy, C. T., and Bui, T. P.: Hydrogen radicals, nitrogen radicals, and the production of ozone in the upper troposphere, Science, 279, 49-53, 1998.

Wohlfrom, K. H., Hauler, T., Arnold, F., and Singh, H.: Acetone in the free troposphere and lower stratosphere: Aircraft-based CIMS and GC measurements over the North Atlantic and a first comparison, Geophys. Res. Lett., 26, 2849-2852, 1999. 